\title{
ANALISIS KINERJA KEUANGAN DENGAN MENGGUNAKAN PENDEKATAN ECONOMIC VALUE ADDED (EVA) PADA PT. INDOSAT TBK YANG TERDAFTAR DI BURSA EFEK INDONESIA PERIODE 2010-2014
}

\author{
Rismansyah *) \\ Totok Sudiyanto *)
}

\begin{abstract}
ABSTRAK
Penulisan dalam penelitian ini, dengan judul mengenai Analisis Kinerja Keuangan dengan Menggunakan Pendekatan Economic Value Added (EVA) pada PT. Indosat Tbk yang terdaftar di Bursa Efek Indonesia periode 2010 - 2014. Dalam permasalahan ini bahwa dengan menggunakan analisis rasio hanya melihat hasil akhir laba perusahaan tanpa memperhatikan resiko yang dihadapi dan tidak memperhatikan biaya modal dalam perhitungannya. Dengan adanya EVA menjadi relevan untuk mengukur kinerja manajemen berdasarkan besar kecilnya nilai tambah ekonomis yang diciptakan perusahaan.

Penelitian ini bertujuan untuk mengetahui kinerja keuangan dengan menggunakan pendekatan EVA. Analisis data yang digunakan dan pembahasan dilakukan dengan menggunkan metode analisis deskriptif kuantitatif, yang bertujuan untuk menganalisis dan mengggambarkan kinerja keuangan perusahaan PT. Indosat Tbk yang terdaftar di BEI dengan menggunakan pendekatan EVA.

Hasil penelitian menunjukan bahwa nilai (1) NOPAT pada tahun 2010-2012 terus mengalami peningkatan dibandingkan pada tahun 2013-2014 penurunan, disebabkan terjadinya penurunan EBIT. (2) WACC pada tahun 2010-2012 dan 2014 mengalami peningkatan, disebabkan karena peningkatan biaya hutang dan mengalami penurunan pada tahun 2013 disebabkan terjadinya penurunan biaya hutang dan biaya modal (3) Modal yang diinvestasikan pada tahun 2010-2014 mengalami penurunan, disebabkan kewajiban jangka panjang terus mengalami penurunan. (4) EVA dapat disimpulkan bahwa nilai EVA pada tahun 2010-2012 EVA > 0 berati EVA positif hal ini menunjukan terjadi nilai tambah ekonomis bagi perusahaan karena para pemegang saham telah berhasil memaksimalkan laba perusahaan, Hal ini tentunya akan menarik minat investor dalam menanamkan sahamnya. Sedangkan pada tahun 2013-2014 EVA < 0 berarti EVA negatif hal ini menunjukan tidak terjadi nilai tambah ekonomis bagi perusahaan karena para pemegang saham belum memaksimalkan laba perusahaan. Hal ini tentunya kurang menarik minat investor dalam menanamkan sahamnya.
\end{abstract}

Kata Kunci : Kinerja Keuangan dan Pendekatan Economic Value Added

\section{PENDAHULUAN}

\subsection{Latar Belakang}

Kinerja manajemen suatu

perusahaan dapat diukur dengan menggunakanrasio keuangan seperti: Net Profit Margin (NPM), Return On Investment (ROI), Return On Assets (ROA) dan Earnings Per Share (EPS).Namun penilaiandengan menggunakan analisis rasio keuanganmemiliki kelemahan yaitu hanyamelihat hasil akhir (laba perusahaan)tanpa memperhatikan resiko yang dihadapi perusahaan dan tidakmemperhatikan biaya modal dalamperhitungannya, karena rasio keuangan yang dihasilkan sangat bergantung pada metode atau perlakuan akuntansi yang digunakan.PT. Indosat Tbk sebagai objek dalam penelitia untuk dianalisis karena perusahaan tersebut dimasa lalu lebih baik dibanding perusahaan lainnyaberikut ini merupakan tabel1.1 yang menggambarkan posisi kinerja keuangan PT. Indosat Tbk selama lima tahun : 
Tabel 1.1

Kinerja Keuangan PT. Indosat Tbk

\begin{tabular}{|l|c|c|c|c|c|}
\hline \multirow{2}{*}{\multicolumn{1}{|c|}{ Uraian }} & \multicolumn{5}{|c|}{ Tahun } \\
\cline { 2 - 6 } & $\mathbf{2 0 1 0}$ & $\mathbf{2 0 1 1}$ & $\mathbf{2 0 1 2}$ & $\mathbf{2 0 1 3}$ & $\mathbf{2 0 1 4}$ \\
\hline Net Profit Margin (NPM)\% & 3,66 & 4,53 & 2,17 & $-11,18$ & $-7,71$ \\
\hline Return On Invesment (ROI)\% & 1,94 & 1,77 & 1,85 & 2,30 & 2,75 \\
\hline Return On Equity (ROE) \% & 4,06 & 4,96 & 2,51 & -16.14 & $-13,09$ \\
\hline Earnings Per Share (EPS) Rp & 132 & 172 & 89,70 & - & - \\
\hline
\end{tabular}

Sumber : Laporan Indonesian Capital Market Directory (ICMD) PT. Indosat Tbk. 2010-2014

Berdasarkan perhitungan yangdilakukan terlihat bahwa kondisi Net Profit Margin (NPM)perusahaan cukup memprihatinkan. Pada tahun 2010 sebesar $3,66 \%$ dan meningkat ditahun 2011 sebesar $1,54 \%$ menjadi $5,20 \%$ dan mengalami penurunan sebesar $3,03 \%$ menjadi $2,17 \%$ ditahun 2012. Pada tahun 2013 menurun sebesar $-11,18$ dan kembali mengalami penurunan sebesar 7,71di tahun 2014, dapat dikatakan kurang baik karena masih dibawah rata-rata industri. Ini juga berarti bahwa barang-barang perusahaan ini relatife rendah atau biaya-biayanya relative tinggi atau keduanya. Return On Investment(ROI) yang diperoleh PT. Indosat Tbk mengalami fluktuasi. Pada tahun 2010 PT. Indosat Tbk mencapai ROI sebesar $1,94 \%$. Pada tahun 2011 mengalami penurunandari tahun sebelumnya menjadi $1,77 \%$ kemudian mengalami peningkatan pada tahun 2012 menjadi 1,85\%. Pada tahun 2013 juga mengalami peningkatan menjadi 2,30\%, dan pada tahun 2014 meningkat menjadi $2,75 \%$.Return On Equity (ROE) yang diperoleh PT. Indosat Tbk jugaberfluktuasi. Pada tahun 2010 PT. Indosat Tbk mencapai ROE sebesar 4,06\%. Pada tahun 2011 mengalami peningkatan yang cukup besar dari tahun sebelumnya menjadi $4,96 \%$ kemudian mengalami penurunan pada tahun 2012 menjadi 2,51\% sedangkan pada tahun 2013 juga mengalami penurunan drastis menjadi $-16,14 \%$, dan pada tahun 2014 meningkat sedikit sebesar $-13,09 \%$. Kondisi laba perlembar saham (Earnings Per Share)pada tahun 2010 yaitu sebesar Rp 132,- per lembar saham. Pada tahun 2011 meningkat sebesar Rp 40,- per lembar saham dari tahun sebelumnya, hal ini terlihat bahwa kesejahteraan pemegang saham meningkat, Pada tahun 2012 mengalami penurunan sebesar $R p$ 82,- per lembar saham ditahun 2013 mengalami penurunan secara drastis sebesar Rp -422,- per lembar saham dan pada tahun 2014 kembali mengalami penurunan sebesar $R p$ $146,27,-$ per lembar saham dari Rp 365,70 ,- per lembar saham dari perhitungan tersebut terlihat bahwa kesejahteraan pemegang saham menurun.Secara umum berdasarkan rasio profibilitas yang terdapat pada Tabel 1.1 menunjukkan kinerja keuangan perusahaan yang kurang baik . pada rasio Net Profit Margin (NPM) mengalami penurunan karena masih dibawah standar industri ini juga dapat berarti bahwa harga barangbarang perusahaan ini relatif rendah atau biaya-biayanya relatif tinggi atau keduanya. Pada rasioReturn On Invesment (ROI) kondisinya kurang baik karena masih dibawah rata-rata industri, rendahnya rasio ini disebabkan rendahnya margin laba karena rendahnya perputaran aktiva. tidak jauh berbeda dengan ROI, 
kondisi ROE juga mengalami penurunan hal ini disebabkan karena masih di bawah rata-rata industri dan kondisi laba perlembar saham juga mengalami penurunan dikarenakan ketidakmampuan perusahaan untuk mencari keuntungan dapat dikatakan buruk. Untuk mengatasikelemahan dari analisis rasioapakah kinerja PT. Indosat Tbk dalam kondisi baik/buruk dapat dilakukan dengan menggunakan pendekatan Economic Value Added(EVA). Adanya Economic Value Added(EVA) menjadi relevan untuk mengukur kinerja yang berdasarkan nilai (value), karena EVAadalah ukuran nilai tambah ekonomis yang dihasilkan oleh perusahaansebagai akibat dari aktivitas atau strategi manajemen. EVA dapat menjadi salah satu tolak ukurinvestor untuk menilai seberapa jauhperusahaan mampu mencapai tujuanperusahaan untuk meningkatkan nilai darimodal yang telah ditanamkan pemegangsaham dalam operasi perusahaan. Selainmelalui analisis rasio yang biasanya telahdicantumkan dalam pelaporan keuangan,investor dapat lebih yakin menanamkanmodalnya dengan melihat nilai EVA padaperusahaan.Berdasarkan uraian diatas, maka penulis tertarik untuk mengetahui kinerja PT. Indosat Tbk yang tercatat di Bursa Efek Indonesia, dengan menggunakan pendekatanEconomic Value Added (EVA). Dengan demikian penulis mengangkat judul penelitian "Analisis Kinerja Keuangan dengan menggunakan pendekatan Economic Value Added (EVA) pada PT. Indosat Tbk yang terdaftar di Bursa Efek Indonesia periode 20102014"

\subsection{Rumusan Masalah \\ Berdasakan latar belakang} masalah di atas, maka dapat dirumuskan bahwa pokok permasalahan pada penelitian ini adalah "Bagaimana kinerja keuangan dengan menggunakan pendekatan Economic Value Added (EVA) pada PT. Indosat Tbk yang terdaftar di Bursa Efek Indonesia?"

1.3 Tujuan Penelitianini bertujuan untuk mengetahui kinerja keuangan PT. Indosat Tbk dengan menggunakan pendekatan Economic Value Added (EVA)padaperiode 2010 sampai dengan 2014.

1.4 Manfaat Penelitiandari hasil penelitian ini diharapkan dapat bermanfaat bagi berbagai pihak antara lain :

a. Bagi Perusahaan hasil penelitian ini diharapkan dapat menjadi masukan bagaimana mengukur kinerja perusahaan sebagai bahan evaluasi untuk meningkatkan kinerja bagi perusahaan.

b. Bagi Peneliti

Selanjutnyadiharapkan dapat digunakan sebagai landasan dan juga digunakan sebagai bahan perbandingan untuk melakukan penelitian selanjutnya yang berkaitan dengan analisis kinerja keuangan dalam bidang dan kajian yang sama.

\section{TEORI PUSAKA}

\subsection{Kinerja Keuangan}

2.1.1 Pengertian Kinerja Keuangan

Menurut Jumingan (2009:239)
kinerja keuangan merupakan
gambaran kondisi keuangan pada
suatu periode tertentu baik
menyangkut aspek penghimpunan
dana maupun penyaluran dana.Dari
uraian diatas dapat disimpulkan bahwa
kinerja keuangan adalah usaha formal
yang telah dilakukan oleh perusahaan
yang dapat mengukur keberhasilan


perusahaan dalam menghasilkan laba, sehingga dapat melihat prospek, pertumbuhan, dan potensi perkembangan baik perusahaan dengan mengandalkan sumber daya yang ada. Suatu perusahaan dapat dikatakan berhasil apabila telah mencapai standar dan tujuan yang telah ditetapkan.

\subsection{Laporan Keuangan \\ 2.2.1 Pengertian Laporan Keuangan}

Menurut Jumingan (2009:4) laporan keuangan pada dasarnya merupakan hasil refleksi dari sekian banyak transaksi yang terjadi dalam suatu perusahaan. Transaksi dan peristiwa yang bersifat financial dicatat, digolongkan dan diringkaskan dengan cara setepat-tepatnya dalam satuan uang dan kemudian diadakan penafsiran untuk berbagai tujuan.Berdasarkan pengertian diatas dapat disimpulan bahwa laporan keuangan merupakan informasi yang berkaitan tentang posisi atau keadaan keuangan perusahaan pada periode tertentu, nantinya akan dipakai oleh pemakainya dalam hal pengambilan keputusan.

\subsection{Rasio Keuangan}

\subsubsection{Pengertian Rasio Keuangan}

Menurut Harahap (2009:297) rasio keuangan adalah angka yang diperoleh dari hasil perbandingan dari satu pos laporan keuangan dengan pos lainnya yang mempunyai hubungan yang relevan dan signifikan (berarti).

\subsection{Economic Value Added (EVA) 2.4.1 Pengertian Economic Value Added (EVA)}

Menurut Brigham dan Houston (2009:111) Economic Value Added
(EVA) adalah suatu estimasi laba ekonomi usaha yang sebenarnya untuk tahun tertentu, dan sangat jauh berbeda dari laba bersih akuntansi dimana laba akuntansi tidak dikurangi dengan biaya ekuitas sementara dalam perhitungan Economic Value Added (EVA) biaya ini akan dikeluarkan.Berdasarkan pendapat diatas dapat disimpulkan bahwa EVA merupakan suatu alat ukur kinerja sebuah perusahaan sekaligus sebagai pengkur nilai tambah yang dihasilakan perusahaan kepada investor (shareholder)dengan

memperhitungkan biaya modal dan juga sebagai dasar dalam pemberian bonus bagi para karyawan yang terdapat pada setiap devisi yang memiliki nilai EVA yang positif.

\subsubsection{Keunggulan Economic Value Added (EVA)}

Menurut Suripto (2015:20) secara konseptual Economic Value Added (EVA) mempunyai keunggulan dibandingankan dengan ukuran kinerja konvensional seperti :

1. EVA sebagai metode pengukuran kinerja keuangan, juga merupakan kerangka kerja manajemen keuangan yang komprehensif, mencangkup berbagai fungsi mulai dari strategic planning, capital allocation, operating budget, performance meansurement, management compensation, hingga internalexternal communication.

2. EVA dimiliki mampu memainkan peran sebagai suatu sistem insentif kompensasi yang dapat mengarahkan perusahaan dalam mencapai tujuan hakikinya, yaitu menciptakan nilai untuk pemegang saham.

3. EVA juga bisa dipakai untuk menstransformasi budaya perusahaan, sehingga semua 
element didalam organisasi menjadi lebih peka dan sadar untuk terus menciptakan nilai bagi perusahaan.

4. EVA dapat mendorong setiap manajer memainkan peran seperti layaknya pemegang saham perusahaan melalui penerapan value based compensation.

\subsubsection{Metode \\ Perhitungan Economic Value Added (EVA)}

Menurut Vales (dalam Iramani, 2005:4) ada beberapa pendekatan yang dapat digunakan untuk mengukur Economic Value Added (EVA), tergantung dari struktur modal dari perusahaaan. Apabila dalam struktur modalnya perusahaan hanya menggunakan modal sendiri, secara sistematis EVA dapat di tentukan sebagai berikut :

$E V A=N O P A T-\left(i_{e} \times E\right)$

Keterangan

NOPAT $=$ Net Operating Profit After, $\mathrm{i}_{\mathrm{e}}=$ Opportunity Cost of Equity, $E=$ Total Equity

Namun apabila dalam struktur modal perusahaan terdiri dari hutang dan modal sendiri secara sistematis EVA dapat dirumuskan sebagai berikut :

$$
\text { EVA }=\text { NOPAT }-(\text { WACC } X \text { TA })
$$

Keterangan :

NOPAT $=$ NetOperating Profit After Taxes(Laba opersai bersih setelah pajak), WACC $=$ Weighted Average Cost of Capital(Biaya modal rata-rata tertimbang), TA=Total Asset (Modal yang diinvestasikan)

\subsubsection{Langkah-langkah Perhitungan Economic Value Added (EVA)}

Langkah-langkah menentukan Economic Value Added(EVA) antara lain :

1. NOPAT (Net Operating Profit After Taxes)

Menurut Brigham dan Houston (2010:65) Net Operating Profit After Taxes (NOPAT) merupakan keuntungan bersih dari operasi perusahaan setelah pajak. NOPAT dapat dihitung dengan menggunakan rumus :

$$
\text { NOPAT = EBIT (1 - Tarif Pajak) }
$$

Keterangan :

NOPAT = Laba bersih setalah pajak, $\mathrm{EBIT}=$ Laba sebelum pajak.

Faktor yang operasional dan laba rugi luar biasa, seperti laba/rugi dari penghentian unit usaha serta beberapa akun laba/rugi lain yang sama sekali tidak berhubungan dengan kegiatan operasional rutin perusahaan dan tidak ada keterangan yang jelas dalam catatan laporan keuangan perusahaan, tidak diikut sertakan dalam perhitungan NOPAT.

\section{Weighted Average Cost of Capital (WACC)}

\section{Menurut}

Prawiranegoro (2008:35) Weighted Average Cost of Capital (WACC) atau biaya modal ratarata tertimbang adalah biaya ekuitas dalam hal ini dapat menggunakan ROE dan biaya masing-masing dikalikan dengan persentase dan hutang dalam struktur modal perusahaan. Adapun rumus untuk menghitung WACC adalah :

$$
\text { WACC }=\frac{\text { Debt }}{\text { Debt }+ \text { Equity }} \text { Cost Of Debt }(I-T)+\frac{\text { Debt }}{\text { Debt }+ \text { Equity }} \text { ROE }
$$


Perusahaan dapat menghitung Weighted Average Cost of Capital(WACC) dengan mengetahui hal-hal sebagai berikut :Jumlah utang dalam struktur modal, pada nilai pasar, Jumlah ekuitas dan struktur modalpada nilai dasar, Biaya hutang, Tingkat pajak, ROE (Return On Equity,Total investasi.

Cost of Capital atau biaya modal mempunyai dua makna, tergantung dari sisi investor atau perusahaan.dari sudut pandang investor, Cost of Capital adalah Opportunity Cost dari dana yang ditanamkan investor pada suatu perusahaan. sedangkan dari sudut pandang perusahaan, cost of capital adalah biaya yang dikeluarkan oleh perusahaan untuk memperoleh sumber dana yang dibutuhkan. Untuk praktisi keuangan, istilah Cost of Capital ini digunakan sebagai berikut :Discount rate untuk membawa cash flow pada masa mendatang suatu proyek ke nilai sekarang, Tarif minimum yang diinginkan untuk menerima proyek baru, Biaya modal dalam perhitungan Economic Value Adde (EVA).

Cost of Capital sangat memepengaruhi oleh hubungan antara risiko dan tingkat pengembalian, dimana semakin besar resiko yang ditanggung oleh investor semakin tinggi pula tingkst pengembalian yang dikehendaki sebelum nilai tambah dapat diciptakan dan semakin tinggi biaya modal yang timbul.Komponen Cost Of Capital terdiri dari :

a. Biaya hutang (Cost Of Debt)adalah tingkat pengembalian yang dikehendaki karena adanya resiko kredit yaitu resiko perusahaan dalam memenuhi kewajiban pembayaran bunga dan pokok hutang, dengan kata lain Cost Of
Debt adalah tarif yang dibayar perusahaan untuk memperoleh tambahan hutang baru jangka panjang di pasar sekarang, mengingat adanya biaya hutang (bunga) dibayar sebelum perusahaan memperhitungkan pajak penghasilan (tax deductible), maka biaya riil yanng ditanggung perusahaan adalah hutang setelah pajak (cost of debt after tax). Biaya hutang dapat dihitung dengan rumus sebagai berikut :

Cost Of Debt $(K d)=K d^{*}(1-t)$

Keterangan:

$\mathrm{Kd}=$ Biaya hutang sebelum pajak, $\mathrm{Kd}^{*}=$ Suku Bunga,

$\mathrm{T}=$ Tarif pajak

Suku bunga dapat dihitung dengan rumus :

$\mathrm{Kd}^{\star}=\frac{\text { Beban Bunga }}{\text { Hutang Jangka Panjang }}$

b. Cost Of Equityadalah tingkat pengembalian yang dikehendaki investor karena adanya ketidakpastian tingkat laba. Kewajiban membayar bunga dan pokok hutang membuat laba bersih perusahaan lebih bervariasi (naik turun) dari pada laba operasi, sehingga menyebabkan timbulnya tambahan resiko. Jadi biaya ekuitas ini mencangkup adanya resiko bisnis dan resiko financial.

Resiko bisnis adalah resiko yang berhubungan dengan baik stabilnya laba, sedangkan resiko financial adalah resiko kesulitan financial dalam hal pembayaran biaya bunga pada pokok hutang. Berdasarkan rumus diatas maka Cost Of Equity dapat dicari dengan menggunakan dengan ROE (Prawiranegoro 2008:35). ROE (Return On Equity) dapat dicari dengan rumus: 
Return On Equity (ROE)

$=$ LabaBersihsetelahpajak

TotalEkuitas

Berdasarkan Keputusan Menteri Keuangan Republik Indonesia No. 740 tahun 1989 tentang Peningkatan
Efesiensi dan Produktivitas Badan Usaha Milik Negara. Berikut inimerupakan daftar skor penilaian kinerja Return On Equity (ROE) menurut Keputusan Menteri BUMN Nomor: KEP-100/MBU/2002.

Tabel 2.1

Daftar skor penilaian ROE

\begin{tabular}{|c|c|}
\hline ROE $\%$ & Skor \\
\hline $15<\mathrm{ROE}$ & 15 \\
\hline $13<\mathrm{ROE}<=15$ & 13,5 \\
\hline $11<\mathrm{ROE}<=13$ & 12 \\
\hline $9<\mathrm{ROE}<=11$ & 10,5 \\
\hline $7,9<\mathrm{ROE}<=9$ & 9 \\
\hline $6,6<\mathrm{ROE}<=7,9$ & 7,5 \\
\hline $5,3<\mathrm{ROE}<=6,6$ & 6 \\
\hline $4<\mathrm{ROE}<=5,3$ & 5 \\
\hline $2,5<\mathrm{ROE}<=4$ & 4 \\
\hline $1<\mathrm{ROE}<=2,5$ & 3 \\
\hline $13<\mathrm{ROE}<=1$ & 1,5 \\
\hline $\mathrm{ROE}<0$ & 1 \\
\hline
\end{tabular}

Sumber: Keputusan Menteri BUMN Nomor: KEP-100/MBU/2002

\section{Modal yang diinvestasikan} Modal yang diinvestasikan adalah jumlah seluruh keuangan perusahaan, terelpas dari kewajiban jangka pendeknya. Modal yang diinvestasikan sama dengan jumlah ekuitas pemegang saham, dan kewajiban jangka panjang. Modal yang diinvestasikan dapat dicari dengan menggunakan rumus sebagai berikut :

\section{Modal yang diinvestasikan = Kewajiban Jangka Panjang + Ekuitas Pemegang Saham}

\subsubsection{Kriteria Economic Value Added (EVA)}

Menurut Widayanto(2004:50) untuk melihat apakah dalam perusahaan telah terjadi penciptaan nilai atau tidak, dapat ditentukan sebagai berikut : a. Jika EVA > 0, maka telah terjadi nilai tambah dalam perusahaan sehingga semakin besar EVA yang dihasilkan maka harapan para penyandang dana dapat terpenuhi dengan baik, yaitu mendapatkan pengambilan investasi yang sama atau lebih dari yang diinvestasikan dan kreditur bisa mendapatkan bunga, keadaan ini menunjukan bahwa perusahaan berhasil menciptakan nilai bagi pemilik modal sehingga menandakan bahwa kinerja keuangannya baik.

b. Jika EVA < 0, maka menunjukan tidak terjadi proses nilai tambah ekonomis bagi perusahaan, karena laba yang tersedia tidak bisa memenuhi harapan para penyandang dana terutama pemegang saham yaitu tidak mendapatkan 
pengembalian yang setimpal dengan investasi yang ditanamkan dan kreditur tetap mendapatkan bunga sehingga dengan tidak ada nilai tambah mengidikasikan kinerja keuangan kurang baik.

c. Jika EVA = 0, maka menunjukan posisi impas karena semua laba yang telah digunakan untuk membayar kewajiban kepada penyandang dana baik kreditur maupun pemegang saham.

\subsection{Penelitian Terdahulu}

Berikut ini beberapa penelitian terdahulu yang dijelaskan secara singkat dan ke dalam bentuk tabel :

Tabel 2.2

Penelitian Terdahulu

\begin{tabular}{|c|c|c|c|c|c|}
\hline No & $\begin{array}{l}\text { Nama dan } \\
\text { tahun } \\
\text { penelitian }\end{array}$ & Judul & Persamaan & Perbedaan & Hasil Penelitian \\
\hline 1 & $\begin{array}{l}\text { Irma Yanti } \\
\text { Nasution } \\
(2009)\end{array}$ & $\begin{array}{l}\text { "Analisis } \\
\text { kinerja } \\
\text { keuangan } \\
\text { berdasarkarka } \\
\text { n Economic } \\
\text { Value Added } \\
\text { (EVA) dan } \\
\text { Market Value } \\
\text { Added (MVA) } \\
\text { pada PT. } \\
\text { Perkebunan } \\
\text { Nusantara IV } \\
\text { Medan" }\end{array}$ & $\begin{array}{l}\text { Menggunakan } \\
\text { metode } \\
\text { (Economic } \\
\text { Value Added) } \\
\text { EVA } \\
\text { Komponen } \\
\text { EVA yang } \\
\text { digunakan } \\
\text { dalam } \\
\text { penelitian ini } \\
\text { adalah } \\
\text { NOPAT(Net } \\
\text { Operating } \\
\text { Profit After } \\
\text { Taxes), WACC } \\
\text { (Weighted } \\
\text { Average Cost } \\
\text { of Capital) dan } \\
\text { Modal yang } \\
\text { diinvestasikan }\end{array}$ & $\begin{array}{l}\text { Menggunkan } \\
\text { metode Market } \\
\text { value Added } \\
\text { (MVA) } \\
\text { Periode 2003- } \\
2007 \\
\text { KomponenFVAya } \\
\text { ngdigunakandala } \\
\text { m penelitian ini } \\
\text { adalah NOPAT, } \\
\text { Equivalent } \\
\text { Depreciation(ED), } \\
\text { dan } \\
\text { Depreciationatau } \\
\text { penyusutan. }\end{array}$ & $\begin{array}{l}\text { Hasil penelitian ini } \\
\text { menunjukkan bahwa } \\
\text { dengan menggunakan } \\
\text { EVA, hanya pada tahun } \\
2003 \text { dan tahun } 2005 \\
\text { manajemen perusahaan } \\
\text { mampu menciptakan nilai } \\
\text { tambah } \\
\text { ekonomissedangkan } \\
\text { dengan menggunakan } \\
\text { analisis FVA perusahaan } \\
\text { menciptakan nilai tambah } \\
\text { finansial yang positif dari } \\
\text { tahun } 2003 \text { - tahun } 2007 \\
\text { terkecuali pada tahun } \\
2006 \text {. }\end{array}$ \\
\hline 2 & $\begin{array}{ll}\mathrm{Ni} & \text { Made } \\
\text { Tatsani Widi } \\
\text { Arini } \\
\\
(2015)\end{array}$ & $\begin{array}{l}\text { Analisis } \\
\text { Kinerja } \\
\text { Keuangan } \\
\text { denganberdas } \\
\text { arkan metode } \\
\text { Economic } \\
\text { Value Added } \\
\text { (EVA)studipad } \\
\text { a P PT. } \\
\text { Telekomunika } \\
\text { si yang } \\
\text { tercatat di } \\
\text { Bursa Efek } \\
\text { Indonesia. }\end{array}$ & $\begin{array}{l}\text { Menggunakan } \\
\text { metode } \\
\text { Economic } \\
\text { value Added } \\
(\text { EVA) }\end{array}$ & $\begin{array}{l}\text { Pada Perusahaan } \\
\text { Telekomunikasi } \\
\text { Periode } \\
2009 . \\
\text { Komponen EVA } \\
\text { yang digunakan } \\
\text { dalam penelitian } \\
\text { ini radalah } \\
\text { NOPAT, Nilai } \\
\text { biaya modal, } \\
\text { Analisis EVA }\end{array}$ & 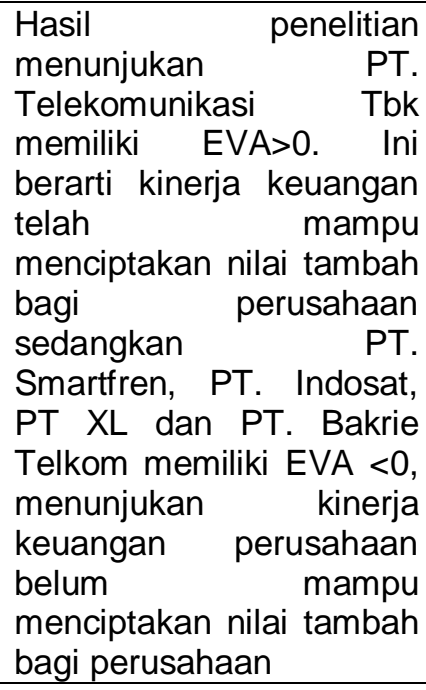 \\
\hline
\end{tabular}




\subsection{Kerangka Pemikiran}

Kerangka pemikiran membantu penulis dalam menguraikan secara sistematis pokok permasalahan dalam penelitian, gambar 1 merupakan kerangka pemikiran dalam penelitian ini. :

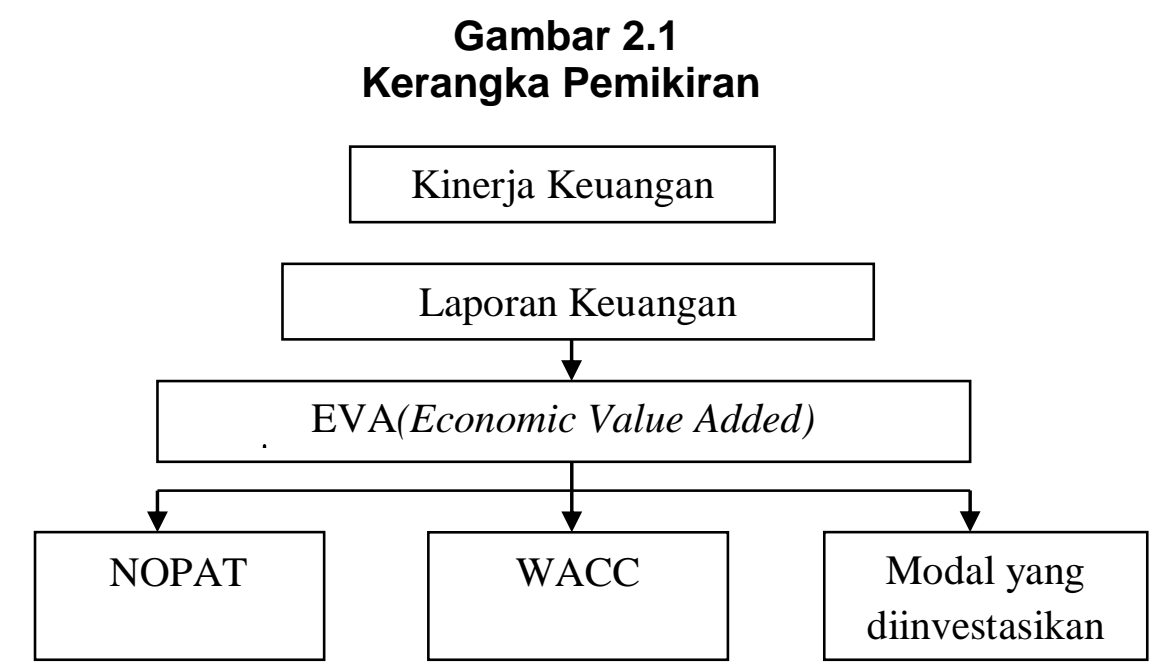

Sumber : Diolah Oleh Penulis 2016

Dari kerangka pemikiran diatas dijelaskan bahwa kinerja keuangan PT. Indosat, Tbk akan dianalisis dari laporan keuangan dengan menggunakan pendekatanEconomic Value Added (EVA)yang terdiri dari : Net Operating Profit After Texes (NOPAT), Weighted Average Cost of Capital(WACC) dan Modal yang diinvestasikan.Kemudian setelah didapatkan hasil perhitungannya akan dinilai kinerja keuangan PT. Indosat Tbk selama lima tahun terakhir yaitu tahun 2010 sampai 2014.

\section{PROSEDUR PENELITIAN}

\subsection{Variabel Penelitian \\ Menurut Sujarweni dan}

Endrayanto (2012:23) Variabel penelitian adalah sesuatu yang berbentuk yang diterapkan oleh peneliti dipelajari dengan seksama sehingga diperoleh informasi berupa data dan diolah dengan statistic sehingga dapat dii tarik kesimpulannya.

\subsection{Definisi Operasional} Menurut Noor (2012:97) Definisi operasional merupakan bagian yang mendefinisikan sebuah konsep/variabel agar dapat diukur, dengan cara melihat pada dimensi (indikator) dari suatu konsep/variable.Adapun Definisi Operasional dalam penelitian ini adalah berikut : 
Table 3.1

Definisi Operasional

\begin{tabular}{|c|c|c|c|}
\hline No & Variabel & Definisi Variabel & Indikator \\
\hline 1. & $\begin{array}{l}\text { Kinerja } \\
\text { keuangan }\end{array}$ & $\begin{array}{l}\text { Kinerja keuangan merupakan } \\
\text { gambaran kondisi keuangan pada } \\
\text { suatu periode tertentu baik menyangkut } \\
\text { aspek penghimpunan dana maupun } \\
\text { penyaluran dana (Jumingan, 2009:239) }\end{array}$ & $\begin{array}{l}\text { 1. Neraca } \\
\text { 2. Laporan laba rugi } \\
\text { 3. Laporan bagian laba } \\
\text { yang ditahan atau } \\
\text { laporan modal } \\
\text { sendiri } \\
\text { 4. Laporan perubahan } \\
\text { posisi keuangan }\end{array}$ \\
\hline 2 & $\begin{array}{l}\text { Metode } \\
\text { Economic } \\
\text { Value } \\
\text { Added } \\
\text { (EVA) }\end{array}$ & $\begin{array}{l}\text { Economic Value Added (EVA) adalah } \\
\text { suatu estimasi laba ekonomi usaha } \\
\text { yang sebenarnya untuk tahun tertentu, } \\
\text { dan sangat jauh berbeda dari laba } \\
\text { bersih akuntansi dimana laba akuntansi } \\
\text { tidak dikurangi dengan biaya ekuitas } \\
\text { sementara dalam perhitungan } \\
\text { Economic Value Added (EVA) biaya ini } \\
\text { akan dikeluarkan (Brigham dan } \\
\text { Houston 2010:111). }\end{array}$ & $\begin{array}{l}\text { 1. NOPAT } \\
\text { 2. WACC yang } \\
\text { 3. Modal diinvestasikan }\end{array}$ \\
\hline
\end{tabular}

\subsection{Populasi dan Sampel}

\subsubsection{Populasi}

Menurut Margono (2010:118) populasi adalah suatu data yang menjadi perhatian kita dalam suatu ruang lingkup dan waktu yang kita tentukan. Populasi yang diteliti dalam penelitian ini adalah laporan keuangan PT. Indosat Tbk 2010-2014.

\subsubsection{Sampel}

Menurut Margono (2010:121) sampel adalah sebagai bagian dari populasi, sebagai contoh yang diambil dengan menggunakan cara-cara tertentu. Sampel yang diteliti dalam penelitian ini adalah metode Economic Value Added (EVA) PT. Indosat Tbk tahun 2010-2014.

\subsection{Metode Penelitian}

Menurut Darmadi (2013:153)

Metode penelitian adalah suatu cara ilmiah untuk mendapatkan data dengan tujuan kegunaan tertentu. Cara ilmiah berarti kegiatan penelitian itu didasarkan pada ciri-ciri keilmuan yaitu rasional, empiris, dan sistematis. Berdasarkan pemaparan di atas dapat disimpulkan bahwa metode penelitian adalah suatu cara ilmiah untuk memperoleh data dengan tujuan dan kegunaan tertentu.Metode penelitian yang digunakan dalam penelitian ini adalah deskriptif kuantitatif, yang bertujuan untuk menganalisis dan mengggambarkan kinerja keuangan perusahaan PT. Inosat Tbk yang terdaftar di BEI dengan menggunakan pendekatan Economic Value Added (EVA).

\subsection{Sumber Data dan Teknik 3.5.1 Sumber Data}

Menurut Noor (2012:138) sumber data adalah sumber informasi yang diterimanya tentang suatu kenyataan atau fenomena empiris, wujudnya dapat merupakan 
seperangkat ukuran kuantitatif atau kualitatif.

\section{Sumber data dapat dibagi menjadi} dua, yaitu :

1. Data primer adalah data yang langsung dari sumbernya.

2. Data sekunder adalah data yang telah disusun, dikembangkan, dan diolah kemudian dicatat, sumber data yang digunakan dalam penelitian ini adalah berupa data sekunder. Data sekunder berupa data laporan keuangan dan data laporan Indonesian Capital Market Directory (ICMD) PT. Indosat Tbk tahun 2010-2014 yang terdaftar di Bursa Efek Indonesia yang beralokasi di Unika Musi Charitas Palembang.

\subsubsection{Teknik Pengumpulan Data}

Menurut Abdulrahman dan Muhidin (2012:84) teknik pengumpulan data adalah cara yang dapat digunakan oleh peneliti untuk mengumpulkan data. Adapun teknik pengumpulan data yang dilakukan penulis sebagai berikut :Dokumentasi adalah metode pengumpulan data melalui peninggalan tertulis, seperti arsip-arsip termasuk buku tentang pendapat, teori, dalil atau hukumhukum lain yang berhubungan dengan masalah penelitian.

\subsection{Teknik Analisis Data}

Menurut Sujarweni (2014:103)

Teknik analisis data dapat diartikan sebagai cara melaksanakan analisis terhadap data dengan tujuan mengelolah data tersebut untuk menjawab rumusan masalah.Teknik analisis data yang digunakan dalam penelitian ini adalah Deskriptif Kuantitatifyang bertujuan untuk menganalisis dan mengggambarkan kinerja keuangan perusahaan PT. Inosat Tbk yang terdaftar di BEI dengan menggunakan pendekatan Economic Value Added (EVA).

\section{Langkah-langkah} meneghitungEconomic Value Added (EVA) antara lain :

\section{Menghitung NOPAT (Net Operating Profit After Taxes)}

Net Operating Profit After Taxes (NOPAT) merupakan keuntungan bersih dari operasi perusahaan setelah pajak. NOPAT dapat dihitung dengan menggunakan rumus :

NOPAT = EBIT (1 - Tarif Pajak)

\section{Menghitung Weighted Average Cost of Capital (WACC)}

Weighted Average Cost of Capital (WACC) atau biaya modal ratarata tertimbang adalah biaya ekuitas dalam hal ini dapat menggunakan ROE dan biaya masing-masing dikalikan dengan presentase dan hutang dalam struktur modal perusahaan. Adapun rumus untuk menghitung WACC adalah :

$$
\mathrm{WACC}=\frac{\text { Debt }}{\text { Debt }+ \text { Equity }} \text { Cost Of Debt }(\mathrm{I}-\mathrm{T})+\frac{\text { Debt }}{\text { Debt }+ \text { Equity }} \mathrm{ROE}
$$

a. Menentukan Biaya Hutang (Cost of Debt)

Cost Of Debt adalah tarif yang dibayar perusahaan untuk memperoleh tambahan hutang baru jangka panjang di pasar sekarang, mengingat adanya biaya hutang (bunga) dibayar sebelum perusahaan memperhitungkan pajak penghasilan (tax deductible), maka biaya riil yanng ditanggung perusahaan adalah hutang setelah pajak (cost of debt after 
tax).Adapun rumus menentukan Biaya Hutang (Cost of Debt)sebagai berikut :

\section{Cost Of $\operatorname{Debt}(K d)=K d^{\star}(1-t)$}

Keterangan:

$\mathrm{Kd}=$ Biaya hutang sebelum pajak,

$\mathrm{Kd}^{*} \quad=$ Suku Bunga,

$\mathrm{T}=$ Tarif pajak

\section{Suku bunga dapat dihitung dengan} rumus :

$K d^{\star}=\frac{\text { Beban Bunga }}{\text { Hutang Jangka Panjang }}$

b. MenentukanCost of equity atau Return On Equity (ROE)

Cost of Equity atau Return On Equity(ROE) adalah tingkat pengembalian yang dikehendaki investor karena adanya ketidakpastian tingkat laba.Adapun rumus Menentukan Cost of equity atauReturn On Equity(ROE) sebagai berikut :

\section{Return On Equity (ROE) \\ LabaBersihsetelahpajak TotalEkuitas}

\section{Menghitung Modal yang diinvestasikan}

Modal yang diinvestasikan adalah jumlah seluruh keuangan perusahaan, terelpas dari kewajiban jangka pendeknya. Modal yang diinvestasikan sama dengan jumlah ekuitas pemegang saham, dan kewajiban jangka panjang. Modal yang diinvestasikan dapat dicari dengan menggunakan rumus sebagai berikut :

\section{HASIL PENELITIAN DAN PEMBAHASAN}

\subsection{Hasil Penelitian}

\subsubsection{Kinerja Keuangan PT. Indosat Tbk}

Kinerja keuangan merupakan gambaran dari pencapaian keberhasilan perusahaan dapat diartikan sebagai hasil yang telah dicapai atas berbagai aktivitas yang telah dilakukan. Dapat dijelaskan bahwa kinerja keuangan adalah suatu analisis yang dilakukan untuk melihat sejauh mana suatu perusahaan telah melaksanakan dengan menggunakan aturan-aturan pelaksanaan keuangan secara baik dan benar.Berikut ini merupakan kinerja keuangan berdasarkan rasio tahun 2010-2014:

Tabel 4.1

Kinerja Keuangan berdasarkan Rasio

PT. Indosat Tbk tahun 2010-2014

\begin{tabular}{|c|c|c|c|c|c|}
\hline \multirow{2}{*}{ Rasio } & \multicolumn{5}{|c|}{ Tahun } \\
\cline { 2 - 6 } & $\mathbf{2 0 1 0}$ & $\mathbf{2 0 1 1}$ & $\mathbf{2 0 1 2}$ & $\mathbf{2 0 1 3}$ & $\mathbf{2 0 1 4}$ \\
\hline Current Ratio (\%) & 55,55 & 55,05 & 75,43 & 53,13 & 40,63 \\
\hline Deviden (\%) & 59,55 & 76,83 & 34,52 & - & - \\
\hline EPS (Rp) & - & - & 89,70 & $-511,97$ & $-365,70$ \\
\hline BV (Rp) & $3.285,03$ & $3.462,68$ & $3.569,31$ & $3.039,71$ & $2.612,47$ \\
\hline DAR (x) & 0,65 & 0,64 & 0,65 & 0,70 & 0,73 \\
\hline
\end{tabular}




\begin{tabular}{|c|c|c|c|c|c|}
\hline DER(x) & 1,94 & 1,77 & 1,85 & 2,30 & 2,75 \\
\hline ROA (\%) & 1,37 & 1,79 & 0,88 & $-4,89$ & $-3,49$ \\
\hline ROE (\%) & 4,06 & 4,96 & 2,51 & $-16,14$ & $-13,09$ \\
\hline GPM (\%) & 17,55 & 13,75 & 14,23 & 6,33 & 100,00 \\
\hline OPM (\%) & 17,55 & 13,75 & 14,23 & - & 2,79 \\
\hline NPM (\%) & 3,66 & 4,53 & 2,17 & $-11,88$ & $-7,71$ \\
\hline Payout Ratio (\%) & - & - & 38,48 & - & - \\
\hline Yield (\%) & 1,10 & 1,36 & 0,54 & - & - \\
\hline
\end{tabular}

Sumber :Laporan Indonesian Capital Market Directory (ICMD) PT. Indosat Tbk. 2010-2014.

\subsubsection{Laporan Keuangan PT. Indosat Tbk}

Laporan keuangan pada dasarnya merupakan hasil refleksi dari sekian banyak transaksi yang terjadi dalam suatu perusahaan. Transaksi dan peristiwa yang bersifat financial dicatat, digolongkan dan diringkaskan dengan cara setepattepatnya dalam satuan uang dan kemudian diadakan penafsiran untuk berbagai tujuan.Berikut ini disajikan laporan keuangan PT. Indosat Tbk tahun 2010-2014 yang terdiri dari Laporan Neraca dan Laporan Laba-Rugi :

Tabel 4.2

Laporan keuangan

PT. Indosat Tbk tahun 2010-2014

(Dalam Jutaan Rupiah)

\begin{tabular}{|c|c|c|c|c|c|}
\hline \multirow{2}{*}{ Neraca } & \multicolumn{5}{|c|}{ Tahun } \\
\hline & 2010 & 2011 & 2012 & 2013 & 2014 \\
\hline Kas dan Setara kas & 2.075 .270 & 2.224 .206 & 3.917 .236 & 2.233 .532 & 3.480 .011 \\
\hline Receivable & 1.558 .457 & 1.446 .729 & 2.061 .160 & 2.284 .633 & 2.101 .127 \\
\hline Persediaan & 105.885 & 75.890 & 52.556 & 36.004 & 49.408 \\
\hline Aktiva Lancar & 6.158 .854 & 6.579 .439 & 8.308 .810 & 7.160 .017 & 8.591 .684 \\
\hline Aset tetap & 43.571 .010 & 42.573 .369 & 41.964 .793 & 42.190 .111 & 40.775 .907 \\
\hline Aset lain-lain & 8.341 & 5.593 & 754.498 & 941.206 & 1.245 .535 \\
\hline Total Aset & 52.818 .187 & 52.172 .311 & 55.225 .061 & 54.520 .891 & 53.254 .841 \\
\hline Pertumbuhan \% & & $-1,22 \%$ & $5,85 \%$ & $-1,28 \%$ & $-2,32 \%$ \\
\hline $\begin{array}{l}\text { Hutang Jangka } \\
\text { Pendek }\end{array}$ & 11.946 .853 & 11.952 .171 & 11.015 .751 & 13.494 .437 & 21.147 .849 \\
\hline $\begin{array}{l}\text { Hutang Jangka } \\
\text { Panjang }\end{array}$ & 22.634 .848 & 21.404 .167 & 24.813 .926 & 24.508 .856 & 17.911 .028 \\
\hline Total Hutang & 34.581 .701 & 33.356 .388 & 35.829 .677 & 38.003 .293 & 39.058 .877 \\
\hline Pertumbuhan \% & & $-3.54 \%$ & $7,41 \%$ & $6,07 \%$ & $2,78 \%$ \\
\hline Modal Dasar & 2000.000 .000 & 2000.000 .000 & 2000.000 .000 & 2000.000 .000 & 2000.000 .000 \\
\hline Modal Disetor & 543.393 & 543.393 & 543.393 & 543.393 & 543.393 \\
\hline $\begin{array}{l}\text { Modal Disetor } \\
\text { (dibagikan) }\end{array}$ & 5.434 & 5.434 & 5.434 & 5.434 & 5.434 \\
\hline Nilai Nominal & 100 & 100 & 100 & 100 & 100 \\
\hline $\begin{array}{l}\text { Pendapatan yang } \\
\text { disimpan }\end{array}$ & 15.359 .289 & 15.870 .673 & 15.981 .167 & 13.011 .589 & 11.024 .419 \\
\hline Total Modal & 17.850 .646 & 18.815 .973 & 19.395 .384 & 16.517 .598 & 14.195 .964 \\
\hline Pertumbuhan \% & & $5,41 \%$ & $3,08 \%$ & $-14,84 \%$ & $-14,06 \%$ \\
\hline
\end{tabular}




\begin{tabular}{|c|c|c|c|c|c|}
\hline Laporan L/R & 2010 & 2011 & 2012 & 2013 & 2014 \\
\hline Total Pendapatan & 19.796 .515 & 20.576 .893 & 22.418 .812 & 23.855 .272 & 24.085 .101 \\
\hline Pertumbuhan \% & & $3,94 \%$ & $8,95 \%$ & $6,41 \%$ & $0,96 \%$ \\
\hline Biaya Pendapatan & 16.322 .571 & 17.746 .794 & 19.228 .789 & 22.346 .056 & - \\
\hline Laba Usaha & 3.473 .944 & 2.830 .099 & $3,190.023$ & $1,509.216$ & 24.085 .101 \\
\hline Beban Pendapatan & 16.322 .571 & 17.746 .794 & 19.228 .789 & - & 23.412 .169 \\
\hline Laba Usaha & 3.473 .944 & 2.830 .099 & 3.190 .023 & - & 672.932 \\
\hline Pertumbuhan \% & & $-19,53 \%$ & $12,72 \%$ & $-100 \%$ & \\
\hline $\begin{array}{l}\text { Penghasilan Lain- } \\
\text { lain }\end{array}$ & -2.392 .127 & 1.648 .199 & -2.728 .405 & -4.843 .053 & -2.608 .883 \\
\hline $\begin{array}{l}\text { Laba sebelum } \\
\text { Pajak }\end{array}$ & 1.081 .817 & 249.397 & -25.798 & -667.378 & -77.879 \\
\hline Pajak & 724,019 & 932.503 & 487.416 & -2.666 .459 & -1.858 .022 \\
\hline Pertumbuhan \% & & $28,80 \%$ & $-47,73 \%$ & $\mathrm{~N} / \mathrm{A}$ & $30,32 \%$ \\
\hline $\begin{array}{l}\text { Laba tahun berjalan } \\
\text { yang diatribusikan }\end{array}$ & - & - & 487.416 & -2.781 .999 & -1.987 .170 \\
\hline $\begin{array}{l}\text { Pendapatan } \\
\text { komprehensif }\end{array}$ & 647.174 & 932.904 & 875.860 & -2.644 .087 & -1861.893 \\
\hline $\begin{array}{l}\text { Komprehensif yang } \\
\text { di atribusikan }\end{array}$ & - & - & 763.550 & -2.750 .627 & -1991.041 \\
\hline
\end{tabular}

Sumber : Laporan Indonesian Capital Market Directory (ICMD) PT. Indosat Tbk. 2010-2014

\subsubsection{Analisis Kinerja Keuangan Dengan Menggunakan Pendekatan Economic Value Added (EVA).}

1. Menghitung Net Operating Profit After Texes (NOPAT)

Net Operating Profit After Texes merupakan keuntungan bersih dari operasi perusahaan setelah pajak.
NOPAT dapat dihitung dengan menggunakan rumus :

$$
\text { NOPAT }=\text { EBIT (1-Tarif Pajak) }
$$

Sebelum dilakukan perhitungan NOPAT, maka terlebih dahulu akan disajikan EBIT dengan 1-Tarif Pajak untuk tahun 2010sampai dengan tahun 2014 yang disajikan melalui tabel 4.3 sebagai berikut :

Tabel 4.3

Data NOPAT PT. Indosat Tbk Tahun 2010-2014 (Dalam Juataan Rupiah)

\begin{tabular}{|l|c|c|c|c|c|}
\hline \multirow{2}{*}{$\begin{array}{c}\text { Komponen } \\
\text { NOPAT }\end{array}$} & \multicolumn{5}{|c|}{ Tahun } \\
\cline { 2 - 6 } & $\mathbf{2 0 1 0}$ & $\mathbf{2 0 1 1}$ & $\mathbf{2 0 1 2}$ & $\mathbf{2 0 1 3}$ & $\mathbf{2 0 1 4}$ \\
\hline EBIT & 3.473 .944 & 2.830 .099 & 3.190 .023 & 1.509 .216 & 672.932 \\
\hline $\operatorname{Tax}$ & $49,42 \%$ & $26,74 \%$ & $5,29 \%$ & $25,02 \%$ & $4,19 \%$ \\
\hline $1-\operatorname{tax}$ & 0,50 & 0,73 & 0,94 & 0,74 & 0,95 \\
\hline
\end{tabular}

Sumber : Laporan Keuangan PT. Indosat Tbk, 2016

Keterangan :

$\mathrm{EBIT}=$ Earning Before Interest and Tax, NOPAT $=$ Net Operating Profit After Tax. 
Berdasarkan data mengenai EBIT dengan 1-Tarif Pajak untuk 5 tahun terakhir yaitu dari tahun 20102014 maka besarnya NOPAT dapat dihitung sebagai berikut :

\section{Tahun 2010}

NOPAT untuk tahun 2010 pada PT. Indosat Tbk dapat dihitung sebagai berikut :

$$
\begin{aligned}
\text { NOPAT } & =3.473 .944(1-49,42 \%) \\
& =3.473 .944(0,50) \\
& =1.726 .972
\end{aligned}
$$

Dari hasil perhitungan NOPAT (laba bersih setelah pajak) tahun 2010 menunjukan nilai sebesar Rp1.726.972 dengan Pajak sebesar 49,42\%.

\section{Tahun 2011}

NOPAT untuk tahun 2011 pada PT. Indosat Tbk dapat dihitung sebagai berikut :

$$
\begin{aligned}
\text { NOPAT } & =2.830 .099(1-26,74 \%) \\
& =2.830 .099(0,50) \\
& =2.065 .972,27
\end{aligned}
$$

Dari hasil perhitungan NOPAT (laba bersih setelah pajak) perusahaan pada tahun 2011 mengalami peningkatan sebesar $19,6 \%$ yaitu naik menjadi $R p$ 2.065.972,27. peningkatan ini disebabkan karena terjadinya penurunan tingkat pajak sebesar 22,68 $\%$ dari tahun sebelumnya.

\section{Tahun 2012}

NOPAT untuk tahun 2012 pada PT. Indosat Tbk dapat dihitung sebagai berikut :

NOPAT

$$
\begin{aligned}
& =3.190 .023(1-5,29 \%) \\
& =3.190 .023(0,94) \\
& =2.998 .612,62
\end{aligned}
$$

Dari hasil perhitungan NOPAT (laba bersih setelah pajak) perusahan pada tahun 2012 mengalami peningkatan sebesar 45,14\% dari Rp2.065.972,27menjadi Rp 2.998.621,62di tahun 2012. Peningkatan NOPAT ini disebabkan peningkatan EBIT sebesar 12,71\% atau naik menjadi Rp 3.190.023dari tahun 2011 sebesar Rp 2.830.099

\section{Tahun 2013}

NOPAT untuk tahun 2013 pada PT. Indosat Tbk dapat dihitung sebagai berikut :

NOPAT $=1.509 .216(1-25,02 \%)$

$$
\begin{aligned}
& =1 \cdot 509 \cdot 216(0,74) \\
& =1 \cdot 116 \cdot 819,84
\end{aligned}
$$

Dari hasil perhitungan NOPAT (laba bersih setelah pajak) perusahaan pada tahun 2013 mengalami penurunan sebesar $168,49 \%$ yaitu $R p$ 2.998.621,62pada tahun 2012 dan menurun menjadi Rp 1.116.819,84pada tahun 2013. Penurunan ini disebabkan karena terjadinya penurunan EBIT sebesar $111,37 \%$ yaitu menurun dari $R p$ 3.190.023menjadi Rp 1.509.216pada tahun 2013. Selain ini terjadi peningkatan pajak sebesar 19,73\% dari tahun sebelumnya.

\section{Tahun 2014}

NOPAT untuk tahun 2014 pada PT. Indosat Tbk dapat dihitung sebagai berikut :

NOPAT $=672.032(1-4,19 \%)$

$$
=672.032(0,95)
$$$$
=639.285,4
$$

Dari hasil perhitungan NOPAT (laba bersih setelah pajak) tahun 2014 NOPAT perusahaan sebesar Rp $639.285,4$ atau menurun sebesar $74,69 \%$ dari tahun 2013 sebesar $\mathrm{Rp}$ 1.116.819,84. Penurunan ini disebabkan karena terjadinya penurunan EBIT sebesar 124,27\% yaitu menurun dari $\mathrm{Rp}$ 1.509.216menjadi Rp672.932. serta penurunan pajak sebesar $20,83 \%$ dari tahun 2013.

\section{Menghitung Weighted Average Cost of Capital (WACC) \\ Weighted Average Cost of Capital(WACC) merupakan biaya}


tertimbang dari berbagai sumber modal sesuai dengan komposisi masing-masing jenis modal. Perhitungan WACC digunakan untuk mengevaluasi tingkat pengembalian suatu proyek. WACC adalah penjumlahan dari hasil perkalian besarnya porsi masing-masing jenis modal dengan biaya modalnya.

Adapun rumus untuk menghitung Weighted Average Cost of Capital(WACC) adalah :

WACC $=\frac{\text { Debt }}{\text { Debt+Equity }}$ Cost of Debt +

$$
\frac{\text { Equity }}{\text { Debt }+ \text { Equity }} \text { ROE }
$$

Menentukan Biaya Hutang
(Cost of Debt)
Cost Of Debt adalah tarif yang dibayar perusahaan untuk memperoleh tambahan hutang baru jangka panjang di pasar sekarang, mengingat adanya biaya hutang (bunga) dibayar sebelum perusahaan memperhitungkan pajak penghasilan (tax deductible), maka biaya riil yanng ditanggung perusahaan adalah hutang setelah pajak (cost of debt after tax). Tingkat Suku bunga dapat dihitung dengan rumus :

$$
\mathrm{Kd}^{\star}=\frac{\text { Beban Bunga }}{\text { Hutang Jangka Panjang }}
$$

Sebelum

melakukan perhitungan biaya hutang maka, menentukan tingkat suku bunga terlebih dahulu yaitu akan disajikan beban bunga dengan hutang jangka panjang tahun 2010-2014 yang disajikan pada tabel 4.4 sebagai berikut:

Tabel 4.4

DataTingkat Suku Bunga (kd*) PT. Indosat Tbk Tahun 2010-2014

\begin{tabular}{|c|c|c|c|c|c|}
\hline \multirow{2}{*}{$\begin{array}{c}\text { Komponen } \\
\text { Suku } \\
\text { Bunga }\end{array}$} & \multicolumn{5}{|c|}{ Tahun } \\
\hline & 2010 & 2011 & 2012 & 2013 & 2014 \\
\hline $\begin{array}{l}\text { Beban } \\
\text { Bunga }\end{array}$ & 2.217 .628 & 1.929 .354 & 2.077 .350 & 2.212 .095 & 2.406 .536 \\
\hline $\begin{array}{l}\text { Hutang } \\
\text { Jangka } \\
\text { Panjang }\end{array}$ & 22.634 .848 & 21.404 .167 & 24.813 .926 & 24.508 .856 & 17.911 .028 \\
\hline
\end{tabular}
Dalam jutaan rupiah

Sumber : Laporan Keuangan PT. Indosat Tbk, 2016.

Berdasarkan tabel diatas mengenai beban bunga dengan hutang jangka panjang untuk tahun 2010-2014 maka besar tingkat suku bunga $\left(\mathrm{kd}^{*}\right)$ dapat dihitung sebagai berikut :

\section{Tahun 2010}

$\mathrm{Kd}^{*}=\frac{2.217 .628}{22.634 .848}=0,0979$

Dari hasil perhitungan Tingkat suku bunga $\left(\mathrm{kd}^{*}\right)$ untuk tahun 2010, menunjukan bahwa $\mathrm{Kd}^{\star}$ yang diperoleh dari data PT. Indosat Tbk sebesar 0,0979 atau $9,79 \%$.

\section{Tahun 2011}

$\mathrm{Kd}^{*}=\frac{1.929 .354}{21.404 .167}=0,0901$

Dari hasil perhitungan Tingkat suku bunga $\left(\mathrm{kd}^{*}\right)$ untuk tahun 2010, menunjukan bahwa $\mathrm{Kd}^{*}$ yang diperoleh dari data PT. Indosat Tbk sebesar 0,0901 atau 9,01\%.

\section{Tahun 2012}

$$
\mathrm{Kd}^{*}=\frac{2.077 .350}{24.813 .926}=0,0837
$$


Dari hasil perhitungan Tingkat suku bunga $\left(\mathrm{kd}^{*}\right)$ untuk tahun 2012, menunjukan bahwa $\mathrm{Kd}^{*}$ yang diperoleh dari data PT. Indosat Tbk sebesar 0,0837 atau 8,37\%.

\section{Tahun 2013}

$\mathrm{Kd}^{*}=\frac{2.212 .095}{24.508 .856}=0,0903$

Dari hasil perhitungan Tingkat suku bunga $\left(k^{*}\right)$ untuk tahun 2012, menunjukan bahwa $\mathrm{Kd}^{\star}$ yang diperoleh dari data PT. Indosat Tbk sebesar 0,0903atau 9,03\%.

\section{Tahun 2014}

$\mathrm{Kd}^{*}=\frac{2.406 .536}{17.911 .028}=0,1314$

Dari hasil perhitungan Tingkat suku bunga $\left(k^{*}\right)$ untuk tahun 2012, menunjukan bahwa $\mathrm{Kd}^{\star}$ yang diperoleh dari data PT. Indosat Tbk sebesar 0,1314 atau 13,14\%.

Setelah dilakukan perhitungan tingkat suku bunga $\left(\mathrm{Kd}^{*}\right)$ maka selanjutnya dapat menentukan biaya hutan. Adapun rumus menentukan Biaya Hutang (Cost of Debt) sebagai berikut :

Cost Of Debt $(\mathrm{Kd})=\mathrm{Kd}^{*}(1-\mathrm{T})$

Keterangan :

$\mathrm{Kd}=$ Biaya hutang sebelum pajak, $\mathrm{Kd}^{*}=$ Suku Bunga, $\mathrm{T}=$ Tarif pajak

Berikut ini merupakan tabel 4.5 Biaya Hutang (Cost of Debt) atau Kd, maka terlebih dahulu akan disajikan tingkat suku bunga dengan 1- tarif pajak untuk tahun 201-2014 yang dapat disajikan pada tabel 4.5 sebagai berikut :

Tabel 4.5

DataBiaya Hutang (Cost of Debt) atau Kd PT. Indosat Tbk Tahun 2010-2014

\begin{tabular}{|c|c|c|c|c|c|}
\hline $\begin{array}{c}\text { Komponen } \\
\text { Biaya } \\
\text { Hutang }\end{array}$ & $\mathbf{2 0 1 0}$ & $\mathbf{2 0 1 1}$ & $\mathbf{2 0 1 2}$ & $\mathbf{2 0 1 3}$ & $\mathbf{2 0 1 4}$ \\
\cline { 2 - 6 } & $\mathbf{0 , 0 9 7 9}$ & $\mathbf{0 , 0 9 0 1}$ & $\mathbf{0 , 0 8 3 7}$ & $\mathbf{0 , 0 9 0 3}$ & $\mathbf{0 , 1 3 1 4}$ \\
\hline $\mathrm{Kd}^{*}$ & 0,50 & 0,73 & 0,94 & 0,74 & 0,95 \\
\hline$(1-\mathrm{T})$ & 0,50 &
\end{tabular}

Sumber : Laporan Keuangan PT. Indosat Tbk, 2016.

Berdasarkan tabel diatas mengenai tingkat suku bunga dengan 1- tarif pajakuntuk tahun 2010-2014 maka besar biaya hutang (kd) dapat dihitung sebagai berikut :

Tahun 2010

Cost Of Debt $(\mathrm{Kd})=0,0979(0,50)=$ $4,89 \%$

Dari hasil perhitungan biaya hutang (kd) untuk tahun 2010, menunjukan bahwa Kd yang diperoleh dari data PT. Indosat Tbk sebesar 4,89\%.

\section{Tahun 2011}

Cost Of $\operatorname{Debt}(\mathrm{Kd})=0,0901(0,73)=$ $6,57 \%$

Dari hasil perhitungan biaya hutang (kd) untuk tahun 2011, menunjukan bahwa Kd yang diperoleh dari data PT. Indosat Tbk sebesar 6,57\%.

\section{Tahun 2012}

Cost Of $\operatorname{Debt}(\mathrm{Kd})=0,0837(0,94)=$ $7,86 \%$

Dari hasil perhitungan biaya hutang (kd) untuk tahun 2012, menunjukan bahwa Kd yang diperoleh dari data PT. Indosat Tbk sebesar 7,86\%.

\section{Tahun 2013}

Cost Of Debt(Kd) $=0,0903(0,74)$

$$
=6,68 \%
$$

Dari hasil perhitungan biaya hutang (kd) untuk tahun 2013, menunjukan bahwa Kd yang diperoleh dari data PT. Indosat Tbk sebesar 6,68\%. 
Tahun 2014

Cost Of Debt(Kd) $=0,1314(0,95)$

$$
=12,48 \%
$$

Dari hasil perhitungan biaya hutang (kd) untuk tahun 2014, menunjukan bahwa $\mathrm{Kd}$ yang diperoleh dari data PT. Indosat Tbk sebesar 12,48\%.

\section{b. Cost Of Equity}

Cost of Equity adalah tingkat pengembalian yang dikehendaki investor karena adanya ketidakpastian tingkat laba. Kewajiban membayar bunga dan pokok hutang membuat laba bersih perusahaan lebih bervariasi (naik turun) dari pada laba operasi, sehingga menyebabkan timbulnya tambahan resiko. Jadi biaya ekuitas ini mencangkup adanya resiko bisnis dan resiko financial. Of Equity dapat dicari dengan menggunakan dengan ROE.Besarnya nilai ROE dapat dihitung dengan menggunakan rumus sebagai berikut :

ROE $=\frac{\text { LabaSetelah Pajak }}{\text { TotalEkuitas }} \times 100 \%$

Sebelum dilakukan perhitungan ROE, maka terlebih dahulu akan disajikan laba setelah pajak dengan total aset untuk tahun 2010 sampai tahun 2014 yang dapat disajikan melalui tabel 4.6 sebagai berikut :

Tabel 4.6

Data ROE PT. indosat Tbk

Tahun 2010-2014

\begin{tabular}{|c|c|c|c|c|c|}
\hline \multirow{2}{*}{$\begin{array}{c}\text { Komponen } \\
\text { ROE }\end{array}$} & \multicolumn{5}{|c|}{ Tahun } \\
\hline & 2010 & 2011 & 2012 & 2013 & 2014 \\
\hline $\begin{array}{l}\text { Laba bersih } \\
\text { setelah } \\
\text { pajak }\end{array}$ & 724.019 & 932.503 & 487.416 & -2.666 .459 & -1.858 .022 \\
\hline $\begin{array}{l}\text { Total } \\
\text { Ekuitas }\end{array}$ & 17.850 .646 & 18.815 .973 & 19.395 .384 & 16.517 .598 & 14.195 .964 \\
\hline
\end{tabular}

Sumber : Laporan Keuangan PT. Indosat Tbk, 2016.

Berdasarkan data mengenai laba bersih setelah pajak dan total ekuitas untuk lima tahun terakhir dari tahun 2010 - 2014 maka besarnya rasio $\mathrm{ROE}$ dapat dihitung sebagai berikut :

Tahun 2010

Besarnya rasio ROE untuktahun 2010, khususnya pada PT. Indosat Tbk dapat dihitung sebagai berikut :

ROE $=\frac{724.019}{17.850 .646} \times 100 \%=4,06 \%$

Dari hasil perhitungan rasio ROE untuk tahun 2010 sebesar 4,06\%, hal ini menujukan kemampuan manajemen untuk memperoleh ROEberarti kondisi perusahaan cukup baik karena masih di atas rata-rata industri.
Besarnya rasio ROE untuk tahun 2011, khususnya pada PT. Indosat Tbk dapat dihitung sebagai berikut :

ROE $=\frac{932.503}{18.815 .973} \times 100 \%=4,96 \%$

Dari hasil perhitungan rasio ROE untuk tahun 2011, menujukan bahwa rasio ROE yang diperoleh sebesar $4,96 \%$ dan ini menunjukan kemampuan manajemen untuk memperoleh ROE yang berarti kondisi perusahaan baik karena diatas rata-rata industri.

\section{Tahun 2012}

Besarnya rasio ROE untuktahun 2012, khususnya pada PT. Indosat Tbk dapat dihitung sebagai berikut :

$\mathrm{ROE}=\frac{487.416}{19.395 .384} \times 100 \%=2,51 \%$

\section{Tahun 2011}


Dari hasil perhitungan rasio ROE untuk tahun 2012, menujukan bahwa rasio ROE yang diperoleh sebesar $2,51 \%$ artinya hasil pengembalian investasi berkurang sebesar $2,45 \%$ dari tahun 2011 dan ini menunjukan ketidakmampuan manajemen untuk memperoleh ROE seiring dengan menurunnya ROI yang berarti kondisi perusahaan kurang baik karena dibawah standar rata-rata industri.

\section{Tahun 2013}

Besarnya rasio ROE untuktahun 2013, khususnya pada PT. Indosat Tbk dapat dihitung sebagai berikut :

$\mathrm{ROE}=\frac{-2.666 .459}{16.517 .598} \times 100 \%=-16,14 \%$

Dari hasil perhitungan rasio ROE untuk tahun 2013, menujukan bahwa rasio ROE yang diperoleh sebesar sebesar $16,14 \%$ artinya hasil pengembalian investasi berkurang sebesar $-13,63 \%$ dari tahun 2012 dan ini menunjukan ketidakmampuan manajemen untuk memperoleh ROE seiring dengan menurunnya ROI yang berarti kondisi perusahaan buruk karena dibawah standar rata-rata industri.

\section{Tahun 2014}

Besarnya rasio ROE untuktahun 2014, khususnya pada PT. Indosat Tbk dapat dihiyung sebagai berikut :

ROE $=\frac{-1.858 .022}{14.195 .964} \times 100 \%=-13,09 \%$

Dari hasil perhitungan rasio ROE untuk tahun 2014. menujukan bahwa rasio ROE yang diperoleh sebesar sebesar $13,09 \%$ ini menunjukan ketidakmampuan manajemen untuk memperoleh ROE seiring dengan menurunnya ROI yang berarti kondisi perusahaan masih buruk karena dibawah standar rata-rata industri.

Berdasarkan Keputusan Menteri Keuangan Republik Indonesia No. 740 Tahun 1989 tentang Peningkatan Efisiensi dan Produktivitas Badan Usaha Milik Negara. Berikut ini merupakan daftar Skor penilaian kinerja ROE menurut Keputusan Menteri BUMN Nomor: KEP100/MBU/2002.

Tabel 4.7

Daftar skor penilaian ROE

\begin{tabular}{|c|c|}
\hline ROE $\%$ & Skor \\
\hline $15<\mathrm{ROE}$ & 15 \\
\hline $13<\mathrm{ROE}<=15$ & 13,5 \\
\hline $11<\mathrm{ROE}<=13$ & 12 \\
\hline $9<\mathrm{ROE}<=11$ & 10,5 \\
\hline $7,9<\mathrm{ROE}<=9$ & 9 \\
\hline $6,6<\mathrm{ROE}<=7,9$ & 7,5 \\
\hline $5,3<\mathrm{ROE}<=6,6$ & 6 \\
\hline $4<\mathrm{ROE}<=5,3$ & 5 \\
\hline $2,5<\mathrm{ROE}<=4$ & 4 \\
\hline $1<\mathrm{ROE}<=2,5$ & 3 \\
\hline $13<\mathrm{ROE}<=1$ & 1,5 \\
\hline $\mathrm{ROE}<0$ & 1 \\
\hline
\end{tabular}

Sumber: Keputusan Menteri BUMN Nomor: KEP-100/MBU/2002 
Tabel 4.8

Penilaian kinerja ROE PT. Indosat Tbk Tahun 2010-2014 berdasarkan Keputusan Menteri BUMN Nomor: KEP-100/MBU/2002

\begin{tabular}{|c|c|c|c|c|c|c|c|c|c|c|}
\hline \multirow{2}{*}{ Rasio } & \multicolumn{2}{|c|}{2010} & \multicolumn{2}{c|}{2011} & \multicolumn{2}{c|}{2012} & \multicolumn{2}{c|}{2013} & \multicolumn{2}{c|}{2014} \\
\cline { 2 - 11 } & Nilai & Skor & Nilai & Skor & Nilai & Skor & Nilai & Skor & Nilai & Skor \\
\hline \multirow{2}{*}{ ROE } & 4,06 & 5 & 4,96 & 5 & 2,51 & 4 & - & 1 & - & 1 \\
\hline
\end{tabular}

Sumber : Laporan keuangan PT. indosat Tbk, data diolah 2016

Berdasarkan tabel 4.8 yaitu penilaiankinerja ROE selama tahun 2010 sampai dengan 2014 terus mengalami penurunan berdasarkan skor masing-masing. Pada tahun 2010 tingkat ROE sebesar 4,06 dengan skor 5 dan mengalami peningkatan ditahun 2011 sebesar 4,96 akan tetapi skor menurut menteri BUMN sebesar 5 yang artinya belum mengalami peningkatan. Pada tahun 2012 mengalami penurunan nilai sebesar 2,45 dengan skor 4 yaitu mengalami penurunan sebesar 1, sedangkan pada tahun 2013 sebesar -16,14 dengan skor 1 yaitu menurun sebesar 3 skor dari tahun 2012 dan ditahun 2014 juga mengalami penurunan sebesar $-13,14$ dengan skor 1 . Penurunan rasio ROE ini disebabkan karena terjadinya penurunan EBIT.Dari perhitungan diatas maka dapat dilakukan perhitungan Weighted Average Cost of Capital(WACC) untuk tahun 2010-2014 dengan data yang disajikan dalam bentuk tabel 4.9 sebagai berikut :

Tabel 4.9

Data WACC PT.Indosat Tbk tahun 2010-2014 (dalam jutaan rupiah)

\begin{tabular}{|c|c|c|c|c|c|}
\hline \multirow{2}{*}{$\begin{array}{l}\text { Komponen } \\
\text { WACC }\end{array}$} & \multicolumn{5}{|c|}{ Tahun } \\
\hline & 2010 & 2011 & 2012 & 2013 & 2014 \\
\hline Debt & 22.634 .848 & 21.404 .167 & 24.813 .926 & 24.508 .856 & 17.911 .028 \\
\hline Equity & 17.850 .646 & 18.815 .973 & 19.395 .384 & 16.517 .598 & 14.195 .964 \\
\hline & & $26,74 \%$ & $5,29 \%$ & $25,02 \%$ & $4,19 \%$ \\
\hline 1 -tax & 0,50 & 0,73 & 0,94 & 0,74 & 0,95 \\
\hline Cost of de & $4,89 \%$ & $6,57 \%$ & $7,86 \%$ & $6,68 \%$ & $12,48 \%$ \\
\hline ROE & $4,06 \%$ & $4,96 \%$ & $2,51 \%$ & $1,61 \%$ & $1,30 \%$ \\
\hline
\end{tabular}

Sumber : Laporan Keuangan PT. Indosat Tbk, data diolah 2016

Berdasarkan tabel 4.7 maka bersarnya Weighted Average Cost of Capital(WACC) dapat dihitung dan dijelaskan sebagai berikut :

Tahun 2010
Weighted Average Cost of Capital(WACC) untuk tahun 2010 pada PT. Indosat Tbk dapat dihitung sebagi berikut :

$\mathrm{WACC}=\frac{22.634 .848}{22.634 .848+17.850 .646} 4,89 \%+\frac{17.850 .646}{22.634 .848+17.850 .646} 4,06 \%=3,15 \%$

Dari hasil perhitungan WACC (WACC) perusahaan adalah sebesar perusahaan, terlihat bahwa pada tahun $3,15 \%$.

2010 biaya modal rata-rata tertimbang 
Tahun 2011

Weighted Average Cost of PT. Indosat Tbk dapat dihitung sebagi Capital(WACC) untuk tahun 2011 pada

berikut :

$\mathrm{WACC}=\frac{21.404 .167}{21404.167+18.815 .973} 6,57 \%+\frac{18.815 .973}{21404.167+18.815 .973} 4,96 \%=4,87 \%$

Dari hasil perhitungan WACC perusahaan, terlihat bahwa pada tahun 2011terjadi peningkatan sebesar $1,72 \%$ sehingga WACC pada tahun 2011 sebesar 4,87\%. Peningkatan WACC ini disebabkan karena terjadinya peningkatan Cost of Equity (Biaya Ekuitas) dalam hal ini ROE perusahaan sebesar $0,9 \%$ (naik dari $4,06 \%$ menjadi $4,96 \%$ ).

\section{Tahun 2012}

Weighted Average Cost of Capital(WACC) untuk tahun 2012 pada PT. Indosat Tbk dapat dihitung sebagi berikut :

$\mathrm{WACC}=\frac{24.813 .926}{24.813 .926+19.395 .384} 7,86 \%+\frac{19.395 .384}{24.813 .926+19.395 .384} 2,52 \%=5,24 \%$

Dari hasil perhitungan WACC perusahaan, terlihat bahwa pada tahun 2012 menurun menjadi 5,24\% dari tahun sebelumnya yang berjumlah $4,87 \%$ (terjadi penurunan 0,37\%). Penurunan ini disebabkan karena terjadinya penurunan Cost of Equity dalam hal ini ROE perushaan sebesar
$2,51 \%$ atau turun sebesar $2,45 \%$ dari tahun 2011 sebesar $4,96 \%$.

\section{Tahun 2013}

Weighted Average Cost of Capital(WACC) untuk tahun 2013 pada PT. Indosat Tbk dapat dihitung sebagi berikut :

$\mathrm{WACC}=\frac{24.508 .856}{24.508 .856+16.517 .598} \quad 6,68 \%+\frac{16.517 .598}{4.508 .856+16.517 .598} 1,61 \%=3,6 \%$

Dari hasil perhitungan WACC perusahaan, terlihat bahwa pada tahun 2013menurun menjadi 3,6\% dari tahun 2012 (turun sebesar 1,65\%) penurunan WACC ini disebabkan karena Cost of Debt perusahaan turun menjadi $6,68 \%$ dari tahun 2012. Penurunan WACC ini juga disebabkan karena terjadinya penurunan Cost of equity menjadi $1,61 \%$ atau turun sebesar $0,9 \%$ dari tahun sebelumnya 2012.

\section{Tahun 2014}

Weighted Average Cost of Capital(WACC) untuk tahun 2014 pada PT. Indosat Tbk dapat dihitung sebagi berikut :

$$
\mathrm{WACC}=\frac{17.911 .028}{17.911 .028+14.195 .964} 12,48 \%+\frac{14.195 .964}{17.911 .028+14.195 .964} 1,30 \%=7,41 \%
$$


Dari hasil perhitungan WACC perusahaan, terlihat bahwa pada tahun 2014 naik sebesar $7,41 \% \%$ atau naik sebesar 3,81\% dari tahun 2013 yaitu sebesar 2,51\%. Peningkatan WACC ini disebabkan peningkatan Cost of debt menjadi 12,48\% dari tahun 2013 yaitu sebesar $6,68 \%$ peningkatan ini sebesar 5,8\%.Berdasarkan uraian diatas terlihat bahwa dari tahun 2010 sampai tahun 2014 perusahaan belum juga berhasil menurunkan biaya modal rata-rata tertimbang atau WACC. Hal ini sangat menghalangi perusahaan untuk dapat mencetak EVA yang positif sehingga tidak dapat memberikan nilai tambah ekonomis bagi perusahaan.

\section{Menentukan Modal yang diinvestasikan \\ Modal yang diinvestasikan} adalah jumlah seluruh keuangan, perusahaan, terlepas dari kewajiban jangka pendeknya. Modal yang diinvestasikan sama dengan jumlah ekuitas pemegang saham, dan kewajiban jangka panjang. Modal yang diinvestasikan dapat dicari dengan menggunakan rumus :

Modal yang diinvestasikan = Kewajiban jangka panjang + Ekuitas pemegang saham

Sebelum dilakukan pethitungan Modal yang diinvestasikan, maka terlebih dahulu akan disajikan data kewajiban jangka panjang dengan ekuitas pemengan saham untuk tahun 2010-2014 yang disajikan pada tabel 4.10 sebagai berikut :

Tabel 4.10

Data Modal yang diinvestasikan PT. Indosat Tbk tahun 2010 - 2014 (Dalam Jutaan Rupiah)

\begin{tabular}{|c|c|c|c|c|c|}
\hline \multirow{2}{*}{$\begin{array}{l}\text { Komponen } \\
\text { (TA) }\end{array}$} & \multicolumn{5}{|c|}{ Tahun } \\
\hline & 2010 & 2011 & 2012 & 2013 & 2014 \\
\hline $\begin{array}{c}\text { Kewajiban } \\
\text { jangka } \\
\text { panjang }\end{array}$ & 22.634 .848 & 21.404 .167 & 24.813 .926 & 24.508 .856 & 17.911 .028 \\
\hline $\begin{array}{c}\text { Ekuitas } \\
\text { pemegang } \\
\text { saham }\end{array}$ & 17.850 .646 & 18.815 .973 & 19.395.384 & 16.517 .598 & 14.195 .964 \\
\hline
\end{tabular}

Sumber : Laporan Keuangan PT. Indosat Tbk, 2016.

Berdasarkan data diatas maka bersarnya Modal yang diinvestasikan dapat dihitung dan dijelaskan sebagai berikut :

Tahun 2010

Modal yang diinvestasikan untuk tahun 2010 pada PT. Indosat Tbk dapat dihitung sebagi berikut :

Modal yang diinvestasikan

$=\operatorname{Rp} 22.634 .848+\operatorname{Rp} 17.850 .646$

$=\operatorname{Rp~40.485.494}$
Dari hasil perhitungan Modal yang diinvestasikan perusahaan, terlihat bahwa pada tahun 2010 sebesar $\mathrm{Rp}$ 40.485.494. yang didapat dari kewajiban jangka panjang dikurangi dengan ekuitas pemegang saham.

\section{Tahun 2011}

Modal yang diinvestasikan untuk tahun 2011 pada PT. Indosat Tbk dapat dihitung sebagi berikut :

Modal yang diinvestasikan 
$=R p 21.404 .167+R p 18.815 .973$

$=\operatorname{Rp} 40.220 .140$

Dari hasil perhitungan Modal yang diinvestasikan perusahaan, terlihat bahwa pada tahun 2011 sebesar Rp 40.485.494. yang didapat dari kewajiban jangka panjang dikurangi dengan ekuitas pemegang saham.

\section{Tahun 2012}

Modal yang diinvestasikan untuk tahun 2012 pada PT. Indosat Tbk dapat dihitung sebagi berikut :

Modal yang diinvestasikan

$=R p$ 24.813.926 + Rp 19.395.384

$=\operatorname{Rp~44.209.310~}$

Dari hasil perhitungan Modal yang diinvestasikan perusahaan, terlihat bahwa pada tahun 2012 sebesar Rp 44.209.310. yang didapat dari kewajiban jangka panjang dikurangi dengan ekuitas pemegang saham.

\section{Tahun 2013}

Modal yang diinvestasikan untuk tahun 2013 pada PT. Indosat Tbk dapat dihitung sebagi berikut :

Modal yang diinvestasikan

$=R p 24.508 .856+R p 16.517 .598$

$=\operatorname{Rp~41.026.454~}$

Dari hasil perhitungan Modal yang diinvestasikan perusahaan, terlihat bahwa pada tahun 2013 sebesar Rp 41.026.454. yang didapat dari kewajiban jangka panjang dikurangi dengan ekuitas pemegang saham.

\section{Tahun 2014}

Modal yang diinvestasikan untuk tahun 2014 pada PT. Indosat Tbk dapat dihitung sebagi berikut :

Modal yang diinvestasikan

$=\mathrm{Rp} 17.911 .028+\mathrm{Rp} 14.195 .964$

$=\operatorname{Rp} 31.106 .992$
Dari hasil perhitungan Modal yang diinvestasikan perusahaan, terlihat bahwa pada tahun 2014 sebesar Rp 31.106.992. yang didapat dari kewajiban jangka panjang dikurangi dengan ekuitas pemegang saham. Berdasarkan tabel 4.8, terlihat bahwa total modal yang diinvestasikan dari tahun 2010 sampai tahun 2014 terus saja mengalami penurunan. Hal ini disebabkan karena menurunnya jumlah pinjaman maupun ekuitas pemegang saham. Penurunan ekuitas pemegang saham ini disebabkan karena adanya laba perusahaan yang diperoleh dari deviden yang dibagikan.

Pada tahun 2011 total modal yang dihasilkan menurun sebesar $0,65 \%$ atau turun dari $\mathrm{Rp}$ 40.485.494 pada tahun 2010 menjadi Rp 40.220.140pada tahun 2011. Pada tahun 2012 modal yang diinvestasikan meningkat sebesar 9,92\% atau naik menjadi Rp 44.209.310dari tahun 2011. Tahun 2013 modal yang diinvestasikan menurun menjadi $\mathrm{Rp}$ 41.026.454 (menurun 7,76\%) dari tahun 2012, dan pada tahun 2014 penurunan kembali modal yang diinvestasikan sebesar $31,88 \%$ atau menurun menjadi Rp 31.106.992.

\section{Menghitung Economic Value Added (EVA)}

Economic Value Added (EVA) adalah suatu estimasi laba ekonomi usaha yang sebenarnya untuk tahun tertentu, dan sangat jauh berbeda dari laba bersih akuntansi dimana laba akuntansi tidak dikurangi dengan biaya ekuitas sementara dalam perhitungan Economic Value Added (EVA) biaya ini akan dikeluarkan. Adapun rumus untuk menghitungan EVA sebagai berikut :

\section{EVA $=$ NOPAT $-($ WACC X TA $)$}

Sebelum dilakukan pethitungan EVA, maka terlebih dahulu akan 
disajikan data NOPAT, WACC dan Modal yang diinvestasikan untuk tahun
2010-2014 yang disajikan pada tabel 4.11 sebagai berikut :

Tabel 4.11

Data EVAPT. Indosat Tbk tahun 2010 - 2014

(Dalam Jutaan Rupiah)

\begin{tabular}{|l|c|c|c|c|c|}
\hline \multirow{2}{*}{$\begin{array}{c}\text { Komponen } \\
\text { EVA }\end{array}$} & \multicolumn{5}{|c|}{ Tahun } \\
\cline { 2 - 6 } & $\mathbf{2 0 1 0}$ & $\mathbf{2 0 1 1}$ & $\mathbf{2 0 1 2}$ & $\mathbf{2 0 1 3}$ & $\mathbf{2 0 1 4}$ \\
\hline NOPAT & 1.726 .972 & $2.065 .972,27$ & $2.998 .621,62$ & $1.116 .819,84$ & $639.285,4$ \\
\hline WACC & $3,15 \%$ & $4,87 \%$ & $5,24 \%$ & $3,6 \%$ & $7,41 \%$ \\
\hline $\begin{array}{l}\text { Modal yang } \\
\text { diinvestasikan }\end{array}$ & 40.485 .494 & 40.220 .140 & 44.209 .310 & 41.026 .454 & 31.106 .992 \\
\hline
\end{tabular}

Sumber : Laporan Keuangan PT. Indosat Tbk, 2016

Keterangan :

Biaya Modal $=$

WACC x Modal yang dinvestasikan

Berdasarkan data diatas maka bersarnya EVA dapat dihitung dan dijelaskan sebagai berikut :

\section{Tahun 2010}

Besarnya EVA untuk tahun 2010 dapat dihitung sebagai berikut :

$$
\begin{aligned}
\text { EVA } & =1.726 .972-(3,15 \% \times 40.485 .494) \\
& =1.726 .972-(1.275 .293) \\
& =451.679
\end{aligned}
$$

Dari perhitungan diatas menunjukan bahwa EVA pada tahun 2010 sebesar Rp 451.679 yang artinya perusahaan mempunyai nilai tambah ekonomis dikarenakan NOPAT sebesar Rp 1.726.972 lebih besar dibandingkan biaya modal sebesar Rp 1.275.293. Sehingga menandakan kinerja keuangan yang baik.

\section{Tahun 2011}

Besarnya EVA untuk tahun 2011 dapat dihitung sebagai berikut :

$$
\begin{aligned}
\text { EVA } & =2.065 .972,27-(4,87 \% \times 40.220 .140) \\
& =2.065 .972,27-(1.958 .720,818) \\
& =107.251,452
\end{aligned}
$$

Dari perhitungan diatas menunjukan bahwa EVA pada tahun 2011 sebesar Rp 107.251,452 yang artinya perusahaan mempunyai nilai tambah ekonomis dikarenakan NOPAT sebesar Rp 2.065.972,27lebih besar dibandingkan biaya modal sebesar $\mathrm{Rp}$ 1.958.720,818. Sehingga menandakan kinerja keuangan yang baik.

\section{Tahun 2012}

Besarnya EVA untuk tahun 2012 dapat dihitung sebagai berikut :

$$
\begin{aligned}
\text { EVA } & =2.998 .621,62-(5,24 \% \times 44.209 .310) \\
& =2.998 .621,62-(2.316 .567) \\
& =682.054,62
\end{aligned}
$$

Dari perhitungan diatas menunjukan bahwa EVA pada tahun 2012 sebesar Rp 682.054,62 yang artinya perusahaan mempunyai nilai tambah ekonomis dikarenakan NOPAT sebesar Rp 2.998.621,62 lebih besar dibandingkan biaya modal sebesar Rp2.316.567. Sehingga menandakan kinerja keuangan yang baik.

\section{Tahun 2013}

Besarnya EVA untuk tahun 2013 dapat dihitung sebagai berikut :

EVA $=1.116 .819,84-(5,24 \% \times 41.026 .454)$

$=1.116 .819,84-(1.476 .952,344)$

$=-360.132,504$

Dari perhitungan diatas menunjukan bahwa EVA pada tahun 2013 sebesar Rp $\quad-360.132,504$ yang artinya perusahaan mempunyai nilai tambah ekonomis dikarenakan NOPAT sebesar Rp 1.116.819,84 lebih kecil dibandingkan biaya modal sebesar $\mathrm{Rp}$ 1.476.952,344. 
meindikasikan kinerja keuangan yang kurang baik.

\section{Tahun 2014}

Besarnya EVA untuk tahun 2014 dapat dihitung sebagai berikut :

EVA $=639.285,4-(7,41 \% \times 31.106 .992)$

$=639.285,4-(2.305 .028,7072)$

$=-360.132,504$

Dari perhitungan diatas menunjukan bahwa EVA pada tahun 2013 sebesar Rp -360.132,504 yang artinya perusahaan mempunyai nilai tambah ekonomis dikarenakan NOPAT sebesar 639.285,4 lebih kecil dibandingkan biaya modal sebesar $\mathrm{Rp}$ 2.305.028,7072.

Sehingga meindikasikan kinerja keuangan yang kurang baik.

\subsection{Pembahasan}

Setelah dilakukan perhitungan dengan menggunkan pendekatan Economic Value Added (EVA)untuk menentukan telah terjadinya nilai tambah ekonomis atau tidak pada PT. Indosat Tbk. Maka selanjutnya akan dilakukan penilaian dengan menggunakan rumus Economic Value Added (EVA). Hal ini dimaksudkan untuk dapat menilai bagaimana kinerja keuangan dengan menggunakan pendekatan EVA pada PT. Indosat Tbk.Untuk menilai kinerja keuangan apakah perusahaan apakah mempunyai nilai tambah atau tidak dapat dilihat dengan kreteria EVA sebagai berikut :

Tabel 4.12

Kriteria Economic Value Added (EVA)

\begin{tabular}{|c|l|}
\hline Kreteria & \multicolumn{1}{|c|}{ Keterangan } \\
\hline Jika EVA $>0$ & $\begin{array}{l}\text { maka telah terjadi nilai tambah dalam perusahaan sehingga } \\
\text { semakin besar EVA yang dihasilkan maka harapan para } \\
\text { penyandang dana dapat terpenuhi dengan baik, yaitu } \\
\text { mendapatkan pengambilan investasi yang sama atau lebih dari } \\
\text { yang diinvestasikan dan kreditur bisa mendapatkan bunga, } \\
\text { keadaan ini menunjukan bahwa perusahaan berhasil menciptakan } \\
\text { nilai bagi pemilik modal sehingga menandakan bahwa kinerja } \\
\text { keuangannya baik. }\end{array}$ \\
\hline Jika EVA $<0$ & $\begin{array}{l}\text { maka menunjukan tidak terjadi proses nilai tambah ekonomis bagi } \\
\text { perusahaan, karena laba yang tersedia tidak bisa memenuhi } \\
\text { harapan para penyandang dana terutama pemegang saham yaitu } \\
\text { tidak mendapatkan pengembalian yang setimpal dengan investasi } \\
\text { yang ditanamkan dan kreditur tetap mendapatkan bunga } \\
\text { sehingga dengan tidak ada nilai tambah mengidikasikan kinerja } \\
\text { keuangan kurang baik. }\end{array}$ \\
\hline Jika EVA =0 & $\begin{array}{l}\text { maka menunjukan posisi impas karena semua laba yang telah } \\
\text { digunakan untuk membayar kewajiban kepada penyandang dana } \\
\text { baik kreditur maupun pemegang saham. }\end{array}$ \\
\hline
\end{tabular}

Sumber : Widayanto 2004 
Tabel 4.13

Perhitungan EVAPT. Indosat Tbk tahun 2010 - 2014

(Dalam Jutaan Rupiah)

\begin{tabular}{|l|c|c|c|c|c|}
\hline \multirow{2}{*}{$\begin{array}{c}\text { Komponen } \\
\text { EVA }\end{array}$} & \multicolumn{5}{|c|}{ Tahun } \\
\cline { 2 - 6 } & $\mathbf{2 0 1 0}$ & $\mathbf{2 0 1 1}$ & $\mathbf{2 0 1 2}$ & $\mathbf{2 0 1 3}$ & $\mathbf{2 0 1 4}$ \\
\hline NOPAT & 1.726 .972 & $2.065 .972,27$ & $2.998 .621,62$ & $1.116 .819,84$ & $639.285,4$ \\
\hline Biaya Modal & 1.275 .293 & $1.958 .720,818$ & 2.316 .567 & $1.476 .952,344$ & $2.305 .028,1072$ \\
\hline EVA & $\mathbf{4 5 1 . 6 7 9}$ & $\mathbf{1 0 7 . 2 5 1 , 4 5 2}$ & $\mathbf{6 8 2 . 0 5 4 , 6 2}$ & $\mathbf{( 3 6 0 . 1 3 2 , 5 0 4 )}$ & $\mathbf{( 1 . 6 6 5 . 7 4 2 , 7 0 7 2 )}$ \\
\hline
\end{tabular}

Sumber : Laporan Keuangan PT. Indosat Tbk, data diolah 2016

Berdasarkan hasil perhitungan EVA pada tabel 4.11. Nilai EVA perusahaan pada tahun 2010 adalah Rp 451.679 nilai EVA yang positif ini menujukan bahwa pada tahun 2010 manajemen telah mampu menciptakan nilai tambah bagi perusahaan karena laba usaha setelah pajak (NOPAT) lebih besar dari biaya modal (WACC $\mathrm{x}$ Modal yang diinvestasikan) sehingga mengakibatkan EVA yang positif. Hal itu menunjukkan bahwa perusahaan memiliki kemampuan untuk memberikan nilai tambah ekonomis kepada perusahaan dan para investor. Dengan adanya peningkatan nilai EVA akan menarik minat para investor untuk menanamkan modalnya pada perusahaan.

Pada tahun 2011 nilai EVA perusahaan menjadi positif menjadi $\mathrm{Rp}$ 107.251,452. Nilai positif ini menujukan bahwa pada tahun 2011 manajemen telah mampu menciptakan nilai tambah bagi perusahaan karena laba usaha setelah pajak (NOPAT) lebih besar dari biaya modal (WACC $\mathrm{x}$ Modal yang diinvestasikan) sehingga mengakibatkan EVA yang positif. Hal itu menunjukkan bahwa perusahaan memiliki kemampuan untuk memberikan nilai tambah ekonomis kepada perusahaan dan para investor. Dengan adanya peningkatan nilai EVA akan menarik minat para investor untuk menanamkan modalnya pada perusahaan.

Pada tahun 2012 nilai EVA perusahaan mengalami peningkatan sebesar 51,9\% menjadi Rp 682.054,62 dari tahun 2011 sebesar $\mathrm{Rp}$ 107.251,452. Nilai positif ini menujukan bahwa pada tahun 2012 manajemen telah mampu menciptakan nilai tambah bagi perusahaan karena laba usaha setelah pajak (NOPAT) lebih besar dari biaya modal (WACC $x$ Modal yang diinvestasikan) sehingga mengakibatkan EVA yang positif. Hal itu menunjukkan bahwa perusahaan memiliki kemampuan untuk memberikan nilai tambah ekonomis kepada perusahaan dan para investor. Dengan adanya peningkatan nilai EVA akan menarik minat para investor untuk menanamkan modalnya pada perusahaan.

Pada tahun 2013 nilai EVA perusahaan menjadi negatif $\mathrm{Rp}$ $360.132,504$. Jadi pada tahun 2013 terjadi penurunan nilai EVA yang disebabkan karena laba usaha setelah pajak (NOPAT) lebih kecil dari biaya modal (WACC $x$ Modal yang diinvestasikan) sehingga mengakibatkan EVA yang negatif. Hal itu menunjukkan bahwa perusahaan belum mampu untuk memberikan nilai tambah ekonomis kepada perusahaan dan para investor. Dengan adanya penurunan nilai EVA akan mengurangi minat para investor untuk menanamkan modalnya pada perusahaan.

Pada tahun 2014 nilai EVA kembali negatif yaitu Rp 1.665.742,7072, jadi EVA pada tahun 2014 mengalami penurunan nilai yaitu 
sebesar $362,53 \%$ dari tahun. Hal itu menunjukkan bahwa perusahaan belum mampu untuk memberikan nilai tambah ekonomis kepada perusahaan dan para investor. Dengan adanya penurunan nilai EVA akan mengurangi minat para investor untuk menanamkan modalnya pada perusahaan.

\begin{tabular}{llr}
\multicolumn{2}{c}{ Sebagimana yang } & $\begin{array}{r}\text { telah } \\
\text { diuraikan di dalam }\end{array}$ \\
sebelumnya, bab & maka & peneliti
\end{tabular}
berpendapat bahwa kinerja keuangan dengan menggunakan pendekatan Economic Value Added (EVA) lebih akurat untuk mengatasi kelemahan dari rasio keuangan yaitu tidak memperhatikan biaya modal dalam perhitungannya, sedangkan pendekatan EVA menggunakan biaya modal dalam perhitungannya. Sebagai bahan evaluasisebaiknya perusahaan menggunakan pendekatanEconomic Value Added (EVA) guna mengetahui posisi keuangansecara mendalam dan akan terlihat apakah perusahaan dapat menciptakan nilai tambah ekonomis atau sebaliknya.

\section{SIMPULAN DAN SARAN}

\subsection{Simpulan}

Berdasarkan analisis kinerja keuangan dengan menggunakan pendekatan Economic Value Added (EVA) pada PT. Indosat Tbk, maka dapat diketahui :

1. Pada tahun 2010laba usaha setelah pajak (NOPAT) sebesar Rp 1.726.972 lebih besar dari biaya modal Rp 1.275.293sehingga mengakibatkan EVA yang positif Rp 451.679,tahun 2011 laba usaha setelah pajak (NOPAT) sebesar Rp 2.065.972,27 lebih besar dari biaya modal Rp 1.958.720,818 sehingga mengakibatkan EVA yang positif $R p$ 107.251,452, tahun 2012 laba usaha setelah pajak (NOPAT) sebesar Rp 2.998.621,62 lebih besar dari biaya modal $\mathrm{Rp}$ 2.316.567 sehingga mengakibatkan EVA yang positif $\mathrm{Rp} 682.054$. Berdasarkan perhitungan tersebut dapat diketahui bahwa pada tahun 2010 sampai dengan tahun 2012 laba usaha setelah pajak (NOPAT) lebih besar dari biaya modal sehingga mengakibatkan EVA yang positif yaitu EVA $>0$. Hal itu menunjukkan bahwa perusahaan memiliki kemampuan untuk memberikan nilai tambah ekonomis kepada perusahaan dan para investor. Dengan adanya peningkatan nilai EVA akan menarik minat para investor untuk menanamkan modalnya pada perusahaan.

2. Sedangkan pada tahun 2013laba usaha setelah pajak (NOPAT) sebesar Rp 1.116.819,84 lebih kecil dari biaya modal sebesar $\mathrm{Rp}$ 1.476.952,344 sehingga mengakibatkan EVA negatif Rp 360.132,504, tahun 2014 laba usaha setelah pajak (NOPAT) sebesar Rp 639.285,4 lebih kecil dari biaya modal sebesar Rp 2.305. 028,1072 sehingga mengakibatkan EVA negatif Rp -1.665.742,7072. dapat diketahui bahwa pada tahun 2013 dan 2014 laba usaha setelah pajak (NOPAT) lebih besar dari biaya modal sehingga mengakibatkan EVA negatif yaitu EVA < 0 . Hal itu menunjukkan bahwa perusahaan belum mampu untuk memberikan nilai tambah ekonomis kepada perusahaan dan para investor. Dengan adanya penurunan nilai EVA akan mengurangi minat para investor untuk menanamkan modalnya pada perusahaan.

Berdasarkan kesimpulan di atas maka peneliti berpendapat bahwa 
kinerja keuangan dengan menggunakan pendekatan Economic Value Added (EVA) lebih akurat untuk mengatasi kelemahan dari rasio keuangan yaitu tidak memperhatikan biaya modal dalam perhitungannya, sedangkan pendekatan EVA menggunakan biaya modal dalam perhitungannya.

\subsection{Saran}

Dari kesimpulan yang sebagaimana telah diuraikan, penulis memberikan saran yang mudahmudahan dapat bermanfaat bagi PT. Indosat Tbk, maka saran yang dapat saya berikan adalah :

1. PT. Indosat Tbk sebaiknya dalam menilai kinerja keuangan perusahaan menggunakan pendekatan Economic Value Added (EVA) karena perhitungan Economic Value Added (EVA) memperhatikan biaya modal dalam perhitungannya sehingga dapat menunjukan kinerja keuangan perusahaan yang lebih akurat.

2. Mengingat kinerja keuangan adalah syarat multak bagi investor sebelum melakukan investasi maka, PT. Indosat Tbk diharapkan untuk meningkatkan kinerja keuangannya sehingga bisa menciptakan nilai tambah ekonomis bagi perusahaan dimasa yang akan datang.

\section{DAFTAR PUSTAKA}

Abdulrahman, Maman dan Muhidin, Sambas Ali. 2012. Panduan Praktis Memahami Penelitian (Bidang SosialAdministrasiPendidikan). CV . Pustaka Setia : Bandung.
Brigham,Eugene $F$, dan joel $F$. Houston, 2009.Dasar-dasar Manajemen Keunagan, buku satu edisi kesepuluh, alih bahasa ali akbar yulianto. Salemba Empat : Jakarta

2010. Dasar-dasar Manajemen Keuangan. Buku 1. (Edisi 11). Salemba Empat.: Jakarta.

Darmdi, Hamid. 2013. Metode Penelitian Pendidikan dan Sosial. Alfabeta :Bandung.

Fahmi, Irham , 2011. Analisis laporan keuangan. Alfabeta :Bandung.
, 2012. Analisis Laporan Keuangan.Cetakan Ke-2. Alfabeta : Bandung

2015. Pengantar Manajemen Keuangan (Teori dan Soal jawab). Cetakan Keempat. Alfabeta: Bandung.

Hanafi, Mamduh M, 2008. Manajemen Keuangan. Edisi kesatu. BPFE : Yogyakarta.

Harahap, Sofyan Syafri. 2009. Analisis Kritis atas Laporan Keuangan. PT. Rajawali Pers : Jakarta.

Hidayati, Ismi Wenda. 2014. Analisis Economic Value Added (EVA) dan Financial Value Added (FVA) sebagai alat ukur kinerja keuangan perusahaan (studi pada PT. Panca Mitra Multiperdana periode 20102014).

Jumingan _2009. Analisis Laporan Keuangan. Cetakan ketiga. PT. Bumi Aksara : Jakarta.

Kasmir.2015. Analisis Laporan Keuangan. Cetakan kedelapan . Rajawali Pers : Jakarta. 
Margono. 2010. Metodologi Penelitian Pendidikan. Jakarta: Rineka Cipta.

Nasution, Irma Yanti. 2009. Analisis Kinerja Keuangan Berdasarkan Economic Value Added (EVA) Dan Financial Value Added (FVA) Pada PT.Perkebunan Nusantara IV Medan : 2009.USU Repository (C) 2008.

Noor, Juliansyah 2012. Metodologi Penelitian. Kencana Prenada Media Group: Jakarta.

Prawiranegoro, Ari Purwanti. 2008. Akuntansi Manajemen, Edisi 2. Penerbit Mitra Wicana Media : Jakarta.

Sari,Muthia. 2015. Analisis Penilaian Kinerja Keuangan Perusahaan dengan menggunakan Metode Economic Value Added (EVA)).(Studi Kasus PT. Bukit Asam (Persero), Tbk yang Terdaftar di Bursa Efek Indonesia). Jurnal Ekonomi dan Bisnis. 2015.
Sujarweni, V. Wiratna.2014. Metodologi Penelitian. Pustaka Baru Perss : Yogyakarta.

Sujarweni, V. W., dan P. Endrayanto. 2012. Statistika untuk Penelitian. Erlangga : Jakarta.

Suripto. 2015. Manajemen Keuangan (Strategi Penciptaan Nilai Perusahaan melalui Pendekatan Economic Value Added). Cetakan Pertama. Graha IImu : Yogyakarta.

Valez, Iramani, Rr, dan Febrian, Erie. 2005. Financial Value Added: Suatu Paradigma Dalam Pengukuran Kinerja Dan Nilai Tambah Perusahaan. Jurnal Akuntansi \& Keuangan, Vol. 7, No. 1, Mei: 1-10.

Widayanto, Gatot. 2004. EVA (NITAMI) : Suatu Trobosan baru dalam pengukuran kinerja perusahaan, Usahawan. 12:5054. 